\title{
Wildfires Disproportionately Affected Jaguars in the Pantanal
}

\author{
Alan De Barros ( $\nabla$ alanbiology@gmail.com ) \\ University of Sao Paulo/ Biosciences Institute https://orcid.org/0000-0002-6870-6849
}

\section{Ronaldo Morato}

Instituto Chico Mendes de Conservação da Biodiversidade, Centro Nacional de Pesquisa e Conservação de Mamíferos Carnívoros https://orcid.org/0000-0002-8304-9779

\section{Christen Fleming}

Smithsonian Conservation Biology Institute, National Zoological Park, Department of Biology, University of Maryland College Park

\section{Renata Pardini}

Instituto de Biociências, Departamento de Zoologia, Universidade de São Paulo

\section{Luiz Gustavo Oliveira-Santos}

Department of Ecology, Federal University of Mato Grosso do Sul

\section{Walfrido Tomas}

Embrapa Pantanal

\section{Daniel Kantek}

Universidade do Estado de Mato Grosso (UNEMAT); Instituto Chico Mendes de Conservação da Biodiversidade (ICMBIO)

\section{Fernando Tortato}

Panthera

\section{Carlos Fragoso}

Associação Onçafari

\section{Fernando Azevedo}

Departamento de Ciências Naturais - Universidade Federal de São João del Rei, Instituto Pró-Carnívoros Jeffrey Thompson

Asociación Guyra Paraguay and CONACYT, Parque Ecológico Asunción Verde https://orcid.org/00000002-5632-1466

\section{Paulo Inácio Prado}

Universidade de São Paulo

\section{Article}

\section{Keywords:}


Posted Date: January 18th, 2022

DOI: https://doi.org/10.21203/rs.3.rs-1216091/v1

License: (c) (i) This work is licensed under a Creative Commons Attribution 4.0 International License. Read Full License

Version of Record: A version of this preprint was published at Communications Biology on October 13th, 2022. See the published version at https://doi.org/10.1038/s42003-022-03937-1. 


\title{
1 Wildfires disproportionately affected jaguars in the Pantanal
}

2

Authors \& affiliations: Alan Eduardo de Barros* ${ }^{1}$, Ronaldo Gonçalves Morato ${ }^{2}$, Christen H. Fleming ${ }^{3,4}$, Renata Pardini ${ }^{5}$, Luiz Gustavo R. Oliveira-Santos ${ }^{6}$, Walfrido M. Tomas ${ }^{7}$, Daniel L.Z. Kantek $^{8}$, Fernando R. Tortato ${ }^{9}$, Carlos Eduardo Fragoso ${ }^{10}$, Fernando C.C. Azevedo ${ }^{11,12}$, Jeffrey J. Thompson ${ }^{13}$, Paulo Inácio de Knegt de López de Prado ${ }^{1}$

*Correspondence: alanbiology@gmail.com

${ }^{1}$ Instituto de Biociências, Departamento de Ecologia, Universidade de São Paulo, Rua do Matão, Trav. 14, no. 321, Cidade Universitária, São Paulo, SP, 05508-090, Brazil.

${ }^{2}$ Centro Nacional de Pesquisa e Conservação de Mamíferos Carnívoros, Instituto Chico Mendes de Conservação da Biodiversidade, Atibaia, SP 12952011, Brazil. 12945010, Brazil.

${ }^{3}$ Department of Biology, University of Maryland College Park, College Park, MD, 20742 USA

${ }^{4}$ Smithsonian Conservation Biology Institute, National Zoological Park, 1500 Remount Road, Front Royal, VA, 22630 USA

Instituto de Biociências, Departamento de Zoologia, Universidade de São Paulo, Rua do Matão, Trav. 14, no. 321, Cidade Universitária, São Paulo, SP, 05508-090, Brazil.

${ }^{6}$ Department of Ecology, Federal University of Mato Grosso do Sul, Campo Grande, MS 79070-900, Brazil.

${ }^{7}$ Empresa Brasileira de Pesquisa Agropecuária (Embrapa Pantanal), Corumbá, MS, Brazil

${ }^{8}$ Universidade do Estado de Mato Grosso (UNEMAT) - Cáceres, MT, Brasil; Instituto Chico Mendes de Conservação da Biodiversidade (ICMBIO), Estação Ecológica de Taiamã (EET) - Cáceres, MT, Brasil.

${ }^{9}$ Panthera, 8 West 40th Street, 18th Floor, New York, USA.

${ }^{10}$ Associação Onçafari, Rua Ferreira de Araújo, 153, Conjunto 14, Sala 4, Pinheiros, 05428-000, São Paulo, SP, Brazil

${ }^{11}$ Departamento de Ciências Naturais - Universidade Federal de São João del Rei. São João Del Rei, MG, Brazil

${ }^{12}$ Instituto Pró-Carnívoros Atibaia, Av. Horácio Neto, 1030 12954-010, Atibaia, SP, Brazil

${ }^{13}$ Asociación Guyra Paraguay and CONACYT, Parque Ecológico Asunción Verde, Asunción, Paraguay

\begin{abstract}
The Pantanal wetland harbours the second largest population of jaguars in the world. Alongside climate and land-use changes, the recent mega-fires in the Pantanal may pose a new threat to the jaguars' long-term survival. To put these growing threats into perspective, we addressed the reach and intensity of fires that have affected jaguar conservation in the Pantanal ecoregion over the last 16 years. The 2020 fires were the most severe in the annual series, followed by 2019, burned $31 \%$ of the Pantanal and affected (I) $45 \%$ of the estimated jaguar population ( $87 \%$ of these affected in Brazil); II) $79 \%$ of the home range (HRs) areas, and (III) $54 \%$ of the protected areas (PAs) within HRs. Fires consumed core habitats and injured several individual jaguars, the Pantanal's apex predator and umbrella species. Displacement, hunger, dehydration, territorial defence, and lower fecundity are among the impacts that may affect the abundance of the species. These impacts are likely to affect other less mobile species and, therefore, the ecological stability of the region. A solution to prevent the recurrence of mega-fires lies in combating the anthropogenic causes that intensify drought conditions, such as implementing actions to protect springs, increasing the number and area of PAs, regulating the use of fire, and allocating fire brigades before dry seasons.
\end{abstract}




\section{Introduction}

The jaguar (Panthera onca) has been considered as Near Threatened for a quarter century ${ }^{1}$. Although several subpopulations have already been recognized as endangered or critically endangere $d^{1-4}$, some stability is still assumed for the Amazon and Pantanal subpopulations ${ }^{1-3,5}$. However, jaguar populations are increasingly threatened due to the accelerated intensification of land use in these areas. The main threats to jaguar conservation ${ }^{1,5}$ are habitat loss ${ }^{4}$, prey poaching ${ }^{4}$, retaliation for livestock depredation ${ }^{6-8}$, pollution from mining and pesticides ${ }^{9}$, increased agricultural activities ${ }^{10}$ and human infrastructure (e.g., increased roadkill rates) ${ }^{11-13}$. Although fire is typically considered a threat to a small proportion of the overall jaguar population ${ }^{1}$, the unprecedented severity of the 2020 fires in the Pantanal ${ }^{14-18}$ suggests that fire may be an unaccounted risk to jaguar conservation in this biome.

An unusual number of fires started in the 2019 wet season in the Pantanal, which intensified in the following dry season ${ }^{14-19}$. These fires reached $56,000 \mathrm{~km}^{2}(31 \%)$ of the Pantanal ecoregion in 2020, an unprecedented record compared with the median of the affected area during the previous 15 years (12\%). In the Brazilian Pantanal, these fires reached $40,000 \mathrm{~km}^{2}$, with a recorded number of fire outbreaks $400 \%$ greater than the median between 1998-2019 ${ }^{17}$. Human-related ignitions ${ }^{14,15}$ combined with a large amount of flammable biomass resulting from a severe drought ${ }^{19-25}$ (SI_Figs.S2) fuelled extensive fires that spread underneath the soil and crossed through areas that are usually flooded or close to water ${ }^{14,20}$.

The fires consumed considerable portions of forest cover and ecologically important areas that would otherwise provide shelter, food, and landscape connectivity to many species ${ }^{14-16}$, directly killing about 17 million vertebrates ${ }^{26}$. Furthermore, the fires impacted biological communities in the Pantanal beyond the affected land extent. For example, the fires destroyed extensive swathes of private and public protected areas (PAs) ${ }^{14,27}$, forest patches at high elevation areas, riparian vegetation, and keystone tree species that provide fruits or nesting sites for birds (e.g., for Hyacinth macaw, Anodorhynchus hyacinthinus) ${ }^{14,20}$. Plants with low resistance and resilience against fire ${ }^{28,29}$ and less agile vertebrates such as anteaters, armadillos, sloths, and reptiles ${ }^{30}$ were probably the most affected species.

Despite jaguars' speed and ability to move large distances, countless individuals were injured during the 2020's mega-fire. Some rescued animals were unable to return to the wild because of the gravity of their injuries, and at least two rescued individuals died ${ }^{16}$. Moreover, fire has a long-term negative effect on gross primary productivity (GPP), which decreases in the following years ${ }^{31}$. In high GPP areas, such as the Pantanal, jaguars have smaller home ranges ${ }^{32}$ and thus occur at higher densities ${ }^{33}$. Given recent and projected increases in global and regional temperatures ${ }^{34,35}$, the recurrence of extreme droughts ${ }^{19,36}$ and uncontrollable fires ${ }^{14-16,20}$ may reduce overall productivity and impact jaguar movements patterns, space use, and habitat selection.

While the consequences of 2020 Pantanal fires warrant further studies, determining the disproportionate impact of these human-induced fires on critical species is the first step in understanding the extent and severity of the damage. Here, we addressed this challenge by investigating how fire has impacted population size, areas selected as home ranges (hereafter HRs), and priority areas for conservation of the jaguar, an umbrella species and apex predator in the Pantanal ecoregion (Brazil, Bolivia, and Paraguay).

To assess the annual impact of fires (2005-2020) $)^{37,38}$ on jaguars, we used two main sources of data, as follows: a) published estimates of jaguar abundance for its entire geographic range 
based on spatial predictions of density and distribution ${ }^{33}$ and b) home range (HRs) areas estimated for 48 resident jaguars monitored between 2005 and 2016 in the Pantanal ${ }^{39}$. We adopted an approach similar to that of a study evaluating the impacts of deforestation and fires on jaguars in the Amazon ${ }^{40}$. We used jaguar density estimates ${ }^{33}$ in areas overlapping with the occurrence of fire gauges as a proxy for the number of animals potentially displaced, injured, or killed by fires ${ }^{40}$. Home-range areas were estimated from GPS tracking data ${ }^{39}$ of 45 jaguar individuals tracked in the Brazilian Pantanal and three in the Paraguayan and Bolivian Pantanal between 2005 and 2016. We selected only individuals whose HRs could be assumed as stable areas, capable of maintaining a resident animal or likely to be occupied by a new individual if conditions were kept similar $\left(2^{\text {nd }} \text { order habitat selection }\right)^{41}$.

We compared remote sensing data on fires that occurred in the last 16 years in the Pantanal to investigate temporal trends of fire affecting (I) the number of jaguars, (II) the proportion and extent of areas selected as home ranges (HRs) by jaguars, and (III) the proportion and extent of legally protected areas (PAs) within the HR of individual jaguars. We focused primarily on assessing the impact of fires on jaguars rather than investigating their causes. However, we included extensive previous evidence to discuss potential causes, impact mitigation, and biodiversity conservation in the Pantanal biome (SI).

\section{Results}

Fire occurrences increased with drought conditions from 2019 to 2020 (Figs. 1, 2). Notably, the 2020 Pantanal fires exhibited the highest mean intensity of the period ( $352.3 \mathrm{~K}$ ), 16 Kelvin higher than the median of the previous 15 years. Fires affected $31 \%$ of the Pantanal, most of it in Brazil (87\% of the total burnt area), corresponding to $33 \%$ of the legal boundaries of the Brazilian biome. However, the severity of the damage reached higher proportions in critical areas for jaguar conservation, drastically affecting their populations and HRs and burning $62 \%$ of the PAs in the Brazilian Pantanal (Figs.1,2,3).

\section{Impacts of fires on jaguars in 2020}

Based on the spatial congruence of raster layers exhibiting fire occurrence (or intensity), jaguar population densities, HRs, and PAs within HRs, we found that:

(I) The impact of fire on jaguar population was exceptionally high in 2020 because the fires coincided spatially with areas of high population density ${ }^{33}$ (Fig.1, Table1). Fires reached $45 \%(n=$ 746 individuals) of the estimated jaguar population throughout the Pantanal ( $n=1668$ individuals). This figure is 3.3 times the median of 15 previous years, if we use the same data on population densities and yearly data on area affected by fires. The Brazilian Pantanal had the highest proportion of jaguars affected by fires $(87 \%, n=649$ individuals), followed by the Bolivian (12\%) and the Paraguayan Pantanal (1\%).

(II) The year 2020 exhibited the highest proportion and extent of jaguar HRs burnt by fires in 16 years, when 38 out of the $48 \mathrm{HRs}$ (79\%) were affected (Figs.2,3). The median burnt extent in jaguar HRs was $78 \%$, corresponding to $2,718 \mathrm{~km}^{2}$. We also documented the highest mean fire intensity, five times higher than the estimated median for the previous 15 years. Significant impacts occurred in the northern Pantanal (Figs.1,3), where $2,098 \mathrm{Km}^{2}$ of HRs were affected, corresponding to a median extent of $97 \%$ of the HR area (mean $=87 \%$ ). We note that the 
inferences about the fires in the HRs throughout the Pantanal were based mainly on jaguars tracked in Brazil $(n=45)$ and only three in Paraguay/Bolivia.

(III) The 2020 fires affected $78 \%$ of the jaguar HRs overlapping with protected areas. Home ranges covered $1,354 \mathrm{~km}^{2}$ of PAs where fires burned $1,054 \mathrm{~km}^{2}$, an area 9.2 times greater than the median area (of PAs within HRs) burned during the previous 15 years in the entire Pantanal. In Brazil, the area of PAs burned within HRs totalled $970 \mathrm{~km}^{2}(72 \%)$. Fires occurred in $54 \%$ ( $\mathrm{n}=$ 26) of the HRs with PAs, with a median extent of burned PAs of $94 \%$. The impacts of fire on PAs were particularly high in the northern Brazilian Pantanal, where the mean PA burned within HRs reached $91 \%$ (median $=100 \%$ ) (Fig.3).

\section{Impacts of fires on jaguars over the last 16 years}

The occurrence, extent, and intensity of fire differed temporally and spatially, affecting estimates differently over the years (SI_Figs.S3, SI_TableS2). A comparison of the impact of fires on jaguar densities, HRs, and PAs within HRs over the last 16 years showed a notable increase in fire extent and intensity in the last two years (Figs.1,2,3; Table1; SI). However, in contrast to 2020, when the northern Brazilian Pantanal was the most affected area, the 2019 fires affected mostly the Bolivian and areas of the southern Brazilian Pantanal. Nevertheless, the 2020 fire affected an overwhelmingly larger area than in other years (Figs.1,2,3; Table1; SI).

I) A high proxy number of jaguars were also affected by fires in 2019, 2010, 2007, and 2005 (Fig.2, Table1), but in all these years, the number of affected individuals was no more than double of the estimated median between 2005-2019.

II) Besides 2020, six years had fire extent and intensity above the historical mean $(\bar{x}=425$ $\mathrm{km}^{2}, 2005-2019$ ) (Fig.3). The years 2019 and 2005 had the second and third largest areas affected, with fires reaching $1,196 \mathrm{~km}^{2}$ and $870 \mathrm{~km}^{2}$ within HRs, respectively. These extents were 3.6 and 2.8 higher than the historical median (median $=329 \mathrm{~km}^{2}, 2005-2019$ ), while in 2020, the fire extent on HRs corresponded to 8.3 times the median. Similarly, fire intensity within HRs in 2019 and 2005 was 2 and 2.4 higher than the historical median (median = 46K), while in 2020, fire intensity was $>5$.

III) In 2011 and 2005, the extent of PAs burned within HRs corresponded to 4.3 and 3.5 times the median (median $=115 \mathrm{~km}^{2}$, based on 2005-2019) and doubled the median in 2009, 2013, and 2016 (Fig.3). Most of the HRs coincided with the protected areas in the Northern Pantanal. Therefore, the largest extent of burned PAs within the HRs matched with the years of higher fire intensity in the northern Pantanal.

Due to the limitations of the original data and sample size, we assumed that the annual estimates of the number of jaguars ${ }^{33}$, HRs, and PAs within HRs were the same. Nonetheless, we included in the $\mathrm{SI}$ a complementary assessment of the impacts of fire on jaguar home ranges (HRs) that occurred during the monitoring period of jaguar individuals and confirmed that the occurrence of fires within HRs depended on the year and region (SI_Notes, SI_Figs.S3, SI_TableS2). 


\section{Discussion}

\section{Fires as a threat to jaguars}

Our results revealed the drastic effects that uncontrolled fires can cause to the apex predator of the Neotropics in a region considered one of the strongholds for the species. The impact of fire on population size, home ranges, and priority areas for jaguar conservation in the Pantanal was exceptionally high in 2020 and proportionally more severe than the nominal $31 \%$ of burned area across the Pantanal (e.g., fires affected $45 \%$ of the jaguars and $79 \%$ of their HRs). Moreover, the annual comparison showed that 2019 was the second-worst year regarding fire impacts (only behind 2020) and equally extreme compared to historical means ${ }^{19}$. Although the Pantanal is well known for its annual and pluri-annual cycles of wet and dry seasons ${ }^{42,43}$, the unusual levels of droughts and fires in subsequent years are alarming. Furthermore, climate assessment and projections of warmer and dryer conditions for the region in the coming years are equally worrying ${ }^{19,21,34,35}$.

We found that $45 \%$ of the jaguar population estimated for the Pantanal occupied areas affected by the 2020 fires (Fig.1). This finding suggests that the fires heavily impacted the jaguars in the Pantanal, even though the major effects were only temporary displacement. This potential displacement may make it more difficult for jaguars to find new suitable areas, thus increasing territorial disputes and decreasing survival and reproductive success. Furthermore, 2019 ranked as the second-highest year of impact of fire on jaguar population estimates among the 16 years considered (Tab. 1, Fig. 1). Importantly, we did not consider cumulative impacts on sequential years or fire recurrence in these estimates. Moreover, the available estimates for jaguar abundance we used ${ }^{33}$ are very conservative and probably underestimated jaguar populations from the Pantanal by a maximum of 3 jaguars $/ 100 \mathrm{~km}^{2}$. However, the reported density of jaguars may reach up to 12.4 jaguars $/ 100 \mathrm{~km}^{2}$ in northern PAs ${ }^{44,45}$ and up to $6.5-7$ jaguars $/ 100 \mathrm{~km}^{2}$ in the southern Pantanal farms $\mathrm{s}^{5,46,47}$. Considering that PAs in the northern Pantanal were severely damaged by the 2020 fires, our results show conservative figures for the actual number of jaguars affected by fires.

We used densities estimated from an ecosystem-wide assessment of impacts as a proxy of the proportion of total population reached by fire each year on a regional scale. We noticed astonishing absolute numbers of individuals affected in the Pantanal in 2019-2020. In 2020, for instance, $87 \%$ of all jaguars affected by fire were in the Brazilian Pantanal. In contrast, the smaller population in the Paraguayan and Bolivian Pantanal had a higher median percentage of individuals affected by fire between $2005-2019$. While $45 \%$ of jaguars were affected by fire in a single year (2020) in the Pantanal, a study ${ }^{40}$ using the same conservative estimates ${ }^{33}$ for jaguar abundance in the Brazilian Amazon revealed that $1.8 \%$ of the population (1422 individuals) was killed or displaced by fire between 2016-2019. Another report estimated that more than 500 individuals were affected by the 2019 fires in the Brazilian and Bolivian Amazon ${ }^{48,49}$. Based on the same density estimates we found that in the Pantanal - a much smaller biome - more jaguars were affected by fire in single years ( $n=513$ in 2019 and $n=746$ in 2020). This recent increase in the number of jaguars affected by fire raises a red flag to the supposed stability of the species in the Pantanal, which is currently globally and locally classified as Near Threatened ${ }^{1,5}$. Therefore, we recommend that future assessments by IUCN specialists carefully consider the frequency and intensity of fires as a potentially significant and growing threat to jaguars in the Pantanal, and their effects on long-term populational trends. 
Quantifying the occurrence of fire on HRs introduced a functional perspective to understanding the impact of fire on individual jaguars. Similarly, our estimates of the number of affected jaguars revealed a vast amount and extent of affected HRs in the last two years (Fig. 2, 3). Jaguars are apex predators, often considered as a keystone ${ }^{50-53}$ and umbrella species ${ }^{40,54}$, highly dependent on large habitat areas ${ }^{55}$, dense native vegetation cover ${ }^{32,56,57}$, and abundance of prey ${ }^{58,59}$. Considering that jaguars often select areas with high environmental integrity, the higher impact of recent fires on HRs corroborates reports showing that $43 \%$ of the 2020 burned area ( $\approx 13 \%$ of the Pantanal) had not been burnt since $2000^{16}$.

In the Pantanal, jaguar HRs are smaller $32,45,60$ and population densities are high ${ }^{5,44-47}$ because the biome is a highly productive system ${ }^{42,44,61}$, with an abundance of prey species and quality habitat, thus allowing jaguars to meet their spatial needs using smaller areas ${ }^{32,45,60}$. However, a trend of increasing drought, rising temperatures, and repeated occurrences of exceptional fires would weaken the Pantanal's resilience ${ }^{19,31}$. These impacts may particularly affect the most sensitive species ${ }^{28,29}$, resulting in a less productive environment ${ }^{31}$, which ultimately decreases the habitat quality of many species. These effects would likely push jaguars to expand their HRs, which would increase disputes for territories and favour a decrease in body size, consequently decreasing reproductive rates and population size.

The extent of protected areas burned is another indicator of how fire can impact biodiversity. Like the HRs, the Pantanal PAs were affected differently in space and time, but the greatest fires occurred in recent years (2019 and 2020). In 2020, fires occurred in 62\% of Brazilian PAs - particularly in northern Pantanal - where several portions of PAs overlapping with jaguar HRs were entirely or almost entirely affected by fires (Fig. 1, 2, 3). In 2019, however, fires affected the Pantanal PAs in Bolivia, Paraguay and southern Brazil more severely in areas that also overlapped with HRs (Fig.1,2,3). Several causes can explain the spread of fires across PAs, including a combination of heat, drought, miscalculated human use of fires, lack of resources and personnel for surveillance and fire control improvement ${ }^{14-16,19,20}$.

The displacement, injuries, and deaths caused by fire to animals within PAs are worrying because these areas are reportedly richer in diversity and biomass ${ }^{62,63}$ (including higher jaguars densities ${ }^{33,44,64}$ ) and are fundamental to safeguarding biodiversity and ensuring the long-term provision of ecosystem services ${ }^{65,66}$. Protected areas provide larger continuous areas of natural vegetation cover and limit contact with humans. However, although some PAs support up to 12.4 jaguars $/ 100 \mathrm{~km}^{2}$ (e.g., Taiamã Ecological Station - TES) ${ }^{44}$, the Pantanal PAs alone would not support viable jaguar populations for more than 50 years ${ }^{64}$. Therefore, sustainable management that allows coexistence in private lands is also fundamental for the conservation of jaguars in the Pantanal $\left.\right|^{5-8}$.

Protected areas of integral protection, such as TES, currently occupy only $5.7 \%$ of the Pantanal ${ }^{42}$ but were the most affected by fires in absolute area (SI_Fig.S5d, SI_Tab.S3) ${ }^{27}$. The total number of PAs, including the sustainable use ones, corresponds to only $5 \%$ of the Brazilian Pantanal (SI_Tabs.S1) $)^{42,67-71}$ and around $10 \%$ of the entire Pantanal ${ }^{42}$, most of it in Bolivia ${ }^{72}$. These percentages are much lower than the minimum of $17 \%$ recommended in the Aichi goals for terrestrial ecosystems ${ }^{42,73}$. Furthermore, PAs are also scarce in the Pantanal headwaters (6\% of

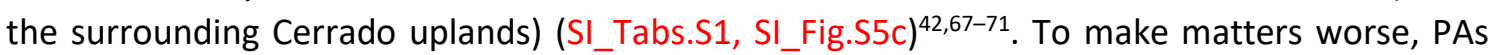
were reduced by almost $20 \%$ in the Brazilian Pantanal in 2007 and have not been expanded in the Cerrado uplands since 2006 (SI_Tab.S1, SI_Fig.S5c) (88 $^{68}$. The relatively small coverage of protected areas in the Pantanal, which serve as refuges, increases the negative effects of fires, 
as jaguars are likely displaced into sub-optimal habitats. Consequently, jaguars and other species may struggle to find equally resource-rich sites after being displaced from PAs. consider the dispersal and reproduction of the species along the Paraguay River ${ }^{74}$, increase the network and size of PAs, and adequately allocate funding and personnel to maintain the PAs. Furthermore, careful implementation of strategies to mitigate the risk of fire ${ }^{15,16,75}$ and other human impacts outside PAs ${ }^{5-11,66,76}$ are urgent needs for conservation of the Pantanal. In any case, our results highlight that to sustain viable populations of jaguars and other species, conservation plans for the Pantanal must account for fire impact on PAs and other vital areas for biodiversity.

Although jaguar HRs often overlap with $\mathrm{PAs}^{44,45,64}$, some individuals may settle in unprotected areas ${ }^{46,47}$. In our sample, we found that 38 HRs partially overlapped with PAs (Fig.1) and $10 \mathrm{HRs}$ did not. On the other hand, considering the sum of the HR extents and the total area overlapped with the PAs, we found that $20 \%$ of the HR extent matched the PAs. Notably, jaguars coexist with different levels of anthropic pressures outside the PAs ${ }^{4-13}$. Jaguar distribution range has been restricted to $63 \%$ of the Pantanal ${ }^{5}$ and even more restricted in the UPRB ${ }^{77}$. Agriculture expansion, particularly cattle ranching and soybean cultivation (SI_Figs.S5) ${ }^{25}$, has been identified as the main causes of jaguars' disappearance or decline due to killing and habitat loss ${ }^{5,6,10}$.

Sustainable use has been advocated as a conservation strategy in the Pantanal, mainly due to the characteristics of the region, where cattle ranching uses as pastures the natural areas restricted by the Pantanal flooding regime 20,42 since the 17 th century ${ }^{20,42}$. In recent years, ecotourism has also gained great importance $61,78,79$. However, there are risks in relying on sustainable use as a core strategy for $90 \%$ of the biome ( $95 \%$ of Brazilian Pantanal), and exposure to human-induced fires is one of them.

Fire is a fundamental factor acting on the dynamics of the Pantanal vegetation ${ }^{20,28,29}$. However, repeated uncontrolled fires can drastically impact forests and other habitats critical to the jaguars and increase the area for cattle ranching, therefore increasing the risk of livestock depredation and retaliatory hunting ${ }^{8}$. Thus, the conservation of the jaguar and other animal species in the Pantanal is critically linked to fire management and the use of private lands because the increased fire may extend and aggravate other anthropic impacts (SI_Fig.S1). This work highlights the significant increase in the extent and severity of recent fires in the Pantanal and how these fires have affected jaguars. Further studies that estimate natural habitat recovery and fire recurrence and assess real-time and long-term effects of fire on jaguars and other species are critical to guide fire management and conservation.

3

\section{5} 6 


\section{Conclusion}

The extent of the recent wildfire in the Pantanal has signalled that fire is a potential threat to the long-term conservation of the jaguar. Furthermore, fires severely affected other species and human activities ${ }^{14,16,20}$, demanding an immediate mitigation plan ${ }^{15,16,75}$. In fact, permanent fire brigades have been established, and an animal rescue centre is under construction in response to the effects of the recent extensive fires in the Pantanal. Although actions are

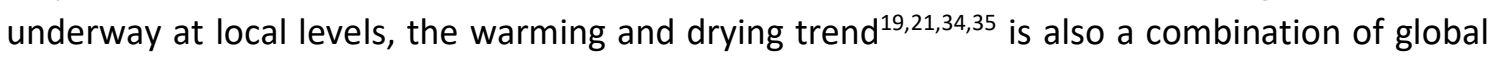
warming ${ }^{34,36}$ and rapid land-use changes ${ }^{15,25,42}$ (SI_Figs.S5), with cumulative impacts in the UPRB and Pantanal wetlands (SI_Fig.S1). Therefore, the immediate reduction of deforestation in the Amazon and Pantanal and the establishment of a forest restoration plan in the UPRB are critical. The lack of sufficient mitigatory actions may throw the Pantanal into a perverse vortex (increasing feedback of cumulative negative impacts, SI_Fig.S1), thus affecting the survival of jaguars and the various species under their umbrella, as well as human welfare.

\section{Methods}

Study area

The Pantanal is the largest wetland in the world ${ }^{14,42}$ and is characterized by a mosaic landscape with floodable and non-floodable areas containing grasslands, forests, open woodlands, and temporary or permanent aquatic habitats ${ }^{25,42,56,80}$. The Pantanal wetland is located within the Upper Paraguay River Basin (UPRB), which comprises a drainage area of $600,000 \mathrm{~km}^{2}(362,380$ $\mathrm{km}^{2}$ in Brazil) $)^{81-84}$. The Pantanal is about $160,000-179,300 \mathrm{~km}^{2}$ distributed across Brazil (78$85 \%)$, Bolivia (15-18\%), and Paraguay $(1-4 \%)^{42,85-87}$. The UPRB contains the river springs that drain into lowlands and floods the Pantanal ${ }^{42,73}$, which stores this water and delivers it slowly westward to the Paraguay River ${ }^{35,42}$. The wet and dry seasons are well-defined, with most annual rainfall falling from November to March and defining a seasonal flood pulse that controls and shapes the biota in the channel-plain system ${ }^{43,88}$. In turn, seasonal floods impact nutrient cycling, vegetation, primary productivity, and wildlife ${ }^{84}$. In addition to flooding, fire is another element that interferes with species abundance and composition ${ }^{28,29}$. While small amounts of fire may promote diversity, the recurrence of high-intensity fires is more likely to be detrimenta| ${ }^{20,28-31}$.

Precipitation, and temperature differ temporally and spatially in the Pantanal wetlands and the Upper Paraguay river basin (UPRB) ${ }^{36,88-92}$. According to the Köppen classification ${ }^{91}$, the UPRB and Pantanal include mainly tropical zones with dry winters (Aw) and annual average precipitation around $1,400 \mathrm{~mm}$. The UPRB also includes a tropical monsoon (Am) region with rainfall between 1,300 and $1,600 \mathrm{~mm}$, a small tropical rainforest (Af) in the south with rainfall between 1,400 and $1,800 \mathrm{~mm}$, and an even smaller region classified as a humid subtropical zone (Cfa) $)^{91}$. Rainfall is usually higher in northern-northeastern $(2000 \mathrm{~mm})$ and southern $(1800 \mathrm{~mm})$ areas, coinciding with the uplands (plateaus) ${ }^{88,91}$. In central Pantanal, rainfall is lower, with about $900 \mathrm{~mm}$ (and $800 \mathrm{~mm}$ near the Bolivian Chaco) ${ }^{88,91,92}$. The Pantanal is bordered by the savanna or Cerrado to the east (which covers the surrounding plateaus), the Amazon to the north, the Atlantic Forest to the southeast (represented by semi-deciduous and deciduous forests), and the Chaco to the southwest. These neighbouring biomes biogeographically influence the Pantanal's biodiversity. The Pantanal is a biodiversity ${ }^{80} /$ ecosystem $^{42}$ services hotspot and was declared a National Heritage Site by the Brazilian Constitution of 1988 and a Biosphere Reserve by UNESCO in $2000^{36,42}$. 
We used Google Earth Engine (GEE) ${ }^{93}$ to obtain near-real-time (NRT) active fire locations in a rasterized form (1 $\mathrm{km}$ resolution) with one or more fire occurrences per pixe ${ }^{37}$. These data were processed by the Land, Atmosphere Near real-time Capability for EOS (LANCE)/ Fire Information for Resource Management System (FIRMS) using the standard MODIS MOD14/MYD14 Fire and Thermal Anomalies product ${ }^{37,38}$. We used fire data from January 2005 to December 31, 2020 in the main analyses. This period corresponded to the jaguar monitoring time (2005-2016), but we also evaluated fire impacts in subsequent years. We used both the occurrence of fires and their intensity (temperature in Kelvin) and adopted a threshold of 325 Kelvin as a determinant of fire occurrence ${ }^{37,94}$. Therefore, we assumed the occurrence only in pixels with fire intensity above this value.

As a spatial limit of the Pantanal, we adopted a merged image of the legal boundaries of the Brazilian Pantanal biome ${ }^{86}$ and Pantanal Ecoregion ${ }^{87}$ within the UPRB, totalling $160,426 \mathrm{~km}^{2}$. We calculated fire occurrences separately within each country's boundaries ${ }^{95}$. The Pantanal area within Brazil corresponded to $150,893 \mathrm{~km}^{2}\left(150,355 \mathrm{~km}^{2}\right.$ of the legal biome ${ }^{86}$ merged with additional Pantanal ecoregion ${ }^{87}$ areas within Brazil). The Pantanal ecoregion ${ }^{87}$ corresponded to $26,399 \mathrm{~km}^{2}$ within Bolivia and 1,970 $\mathrm{km}^{2}$ within Paraguay. Vectors for countries, ecoregion, and PAs boundaries were rasterized and resampled to match the $1-\mathrm{km}$ resolution and then reclassified using $\mathrm{GEE}^{72,93}$ and the raster package ${ }^{96}$ from $\mathrm{R}$ statistical software ${ }^{97}$. Estimates of annual land-use changes and wetland extent were based on MapBiomas collection $5.0^{25}$ and complemented with data on rainfall ${ }^{22,23}$ and river water levels ${ }^{24}$. The polygons of protected areas were downloaded from GEE ${ }^{72,93}$ and Brazilian Ministry of Environment geodatabase ${ }^{67,70}$. Some private protected areas may be missing because data were unavailable ${ }^{42}$. We supplemented our discussion using complementary information on $\mathrm{PAs}^{68-71}$, estimates of fire impact ${ }^{14,27}$, relationships between fires and precipitation, river water levels, land-use change, and wetland extent, among other data (SI).

We evaluated the impact of fire in the Pantanal by overlapping raster images of the annual occurrence of fires and the Pantanal extent within each country. We reclassified the Pantanal boundaries so that the sum of the cell values was 1 and then multiplied these values by the raster of fire occurrence. This multiplication resulted in a distribution of the occurrence of fires, with the sum of these cells corresponding to an estimated proportion of the impact of fire in the Pantanal of each country. The mean (or median) annual fire intensity was calculated based on the pixels' mean (or median) values.

A similar process of resampling and reclassifying raster images was applied to evaluate the impact of fire on the PAs of the Pantanal. First, we calculated the extent of PAs in the Pantanal. Second, we calculated the extent of PAs impacted by fires - i.e., the probability of fire occurrence per pixel based on the multiplication of the Pantanal PAs raster by the fire occurrence raster. Then, we calculated the ratio between the PAs impacted by fire and the total extent of the Pantanal PAs in each country.

\section{Proxy for the number of jaguars affected by fires in the Pantanal}

We used estimates of the population density of jaguars ${ }^{33}$ occurring in the pixels reached by fires $^{37}$ as a proxy for the number of jaguars affected (e.g., potentially displaced, injured, or killed by fires ${ }^{40}$ ) in 2020 and the previous 15 years. We used these population density estimates in a 
similar way to a study evaluating a proxy for the number of jaguars displaced in burned areas in the $\mathrm{Amazon}^{40}$.

In the study by Jędrzejewski et al. ${ }^{33}$ population estimates were derived from 80 studies of camera traps spread across the jaguar distribution between 2002 to 2014. Population density and probability of occurrence were then modelled as response variables to environmental covariates, such as net primary productivity ${ }^{33}$. Finally, to adjust the estimates to the actual jaguar range ${ }^{1}$, the authors multiplied the population density estimate by the probability of occurrence estimate ${ }^{33}$.

We thus clipped the raster image output from Jędrzejewski et al. ${ }^{33}$ containing jaguar abundance estimates ${ }^{33}$ with the Pantanal polygon masks of each country and adjusted the resolution to $1 \mathrm{~km}$. As the original information corresponded to the estimated number of jaguars per $100 \mathrm{~km}^{2}$, we converted this information to a $1-\mathrm{km}$ resolution by dividing the cells by 100 , thus obtaining the number of jaguars per $1 \mathrm{~km}^{2}$. Therefore, the sum of the pixels corresponded to a proxy for the total number of jaguars within the boundary of the Pantanal area to be assessed (for Brazil, Bolivia, Paraguay, or the entire Pantanal).

Next, we selected the pixels of jaguar density estimates overlapping with the occurrence of fire. Thus, the sum of the pixels with fire records corresponded to a proxy for the estimated number of individuals impacted by fire in the Pantanal in each country. Finally, we calculated the correspondent percentages of jaguars impacted by the fire.

Importantly, the estimates by Jędrzejewski et al. ${ }^{33}$ were conservative (with a limited number of study sites in the Pantanal), and their model favoured forested regions. Moreover, these authors did not explicitly consider other important factors that may affect abundance in the Pantanal, such as prey density ${ }^{44,45}$. Despite these shortcomings, the map by Jędrzejewski et al. ${ }^{33}$ is still the best available proxy to point the number and spatial variations of jaguars, and it has already been successfully used for comparisons and estimates of fire impacts on jaguars from the $\mathrm{Amazon}^{40}$.

\section{Jaguar home range estimates}

We used published data ${ }^{39}$ to estimate jaguar home ranges and evaluate the impact of fire on home ranges (HRs) during 2020 and the previous 15 years. We gathered GPS data on the movement of 56 individual jaguars tracked at seven sites $^{33}$ in the Brazilian, Paraguayan, and Bolivian Pantanal. From these data, we used 48 individuals classified as residents. We excluded individuals with insufficient data or classified as non-residents (SI_Figs.S3, S4, S5). Individual residency status was evaluated by analysing the asymptotic behaviour of semi-variograms

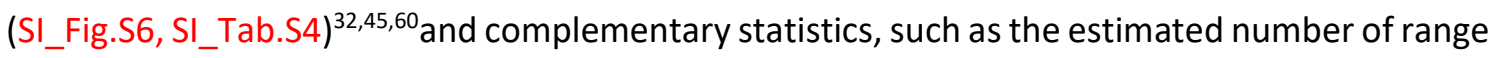
crossings ( $\mathrm{N}_{\text {area }}$ or DOFarea), with the continuous-time time movement modelling (ctmm) $R$ package ${ }^{98,99}$. Individuals were classified as residents if they inhabited the home-range area during the monitoring period, had $\mathrm{DOF}_{\text {area }}>5^{100}$, or obtained an asymptote in their semi-variogram ${ }^{32,45,60}$ (SI_Fig.S6, SI_Tab.S4). The minimum sampling period used was 27 days, and the maximum was 591 days (SI).

Data cleaning and preparation for temporal order and duplicates were performed in $\mathrm{R}^{97}$, using amt ${ }^{101}$ and $\mathrm{ctmm}^{98,99}$ packages. We calculated individual jaguar home ranges as indicative of areas selected as home ranges (HRs) using the Autocorrelated Kernel Density Estimator (AKDE), from the ctmm $\mathrm{R}$ package $\mathrm{e}^{98,99}$, and the same grid alignment and resolution as the fire 
raster images. From each $A K D E$, we calculated the probability mass function, an indicator of the intensity of jaguar space use within the AKDE-derived raster images, and multiplied this value by the raster images of fire occurrence. The sum of the resulting probabilities at each pixel meant the proportion of individual jaguar HRs impacted by the fire. The annual fire intensities within HRs were calculated by averaging the fire intensity values recorded at each pixel. Lastly, we calculated the frequency distribution of jaguars in PAs, i.e., the extent of HRs included in PAs. Then we estimated the extent of HRs containing PAs with fire occurrence. To do so, we first multiplied the estimated probability mass function of each jaguar (corresponding to the jaguars' AKDE) by the occurrence of PAs. Next, we multiplied these two layers by the raster images of fire occurrence. These analyses (Fig.2,3) consisted of comparing the impact of fire in all HRs $(n=48)$ over time (2005-2020).

We performed an analysis of variance (ANOVA) to understand the effect of year and region of fire occurrence on jaguar HRs and compared models including each variable alone, additive and interaction effects (SI_Tab.S2). Furthermore, we considered the percentage of fire occurrence matching individual jaguar HRs areas only during the GPS monitoring period and compared these analyses with those projected for many years (SI_Figs.S3).

Code availability: We followed J. Fieberg and J. Signer ${ }^{101}$ scripts for cleaning and preparing the basic movement data. The analyses of the jaguar home range followed Fleming et al. ${ }^{98,99}$. First, we ran AKDE Home Ranges in R. Then, we entered and merged all the HRs in GEE and reran AKDE in a common grid with the fire raster output.

\section{A) Google Earth Engine example from 2020 (Main Code)}

\section{https://code.earthengine.google.com/fOae619db0404f606562d33290416277}

The same code was applied filtering other years (2001 to 2019).

B) R scripts with raster operations accounting for fire impacts on areas, jaguar abundances and home ranges are available at https://doi.org/10.6084/m9.figshare.17698595.v1 .

Data availability: Original jaguar data ${ }^{39}$ associated with this publication are available at https://doi.org/10.5061/dryad.2dh0223 (Dryad Digital Repository). We provided raw and processed data at https://doi.org/10.6084/m9.figshare.17698595.v1 .

\section{References}

1. Quigley, H., Foster, R., Petracca, L., Payan, E., Salom, R. \& Harmsen, B., 2017. Panthera onca (errata version published in 2018). The IUCN Red List of Threatened Species 2017; doi:10.2305/IUCN.UK.2017-3.RLTS.T15953A50658693.en. (2018).

2. De la Torre, J. A. et al. The jaguar's spots are darker than they appear: assessing the global conservation status of the jaguar Panthera onca. Oryx 52, 300-315 (2018).

3. Desbiez, A. L. J. \& Paula, R. C. D. Species conservation planning: the jaguar National Action Plan for Brazil. Cat News 7: 4- 7. IUCN SSC Cat Specialist Group, Muri, Switzerland. (2012).

4. Paviolo, A. et al. A biodiversity hotspot losing its top predator: The challenge of jaguar conservation in the Atlantic Forest of South America. Scientific Reports 6, 37147 (2016).

5. Cavalcanti, S., Azevedo, F., Tomas, W., Boulhosa, R. \& Crawshaw, P. The status of the jaguar in the Pantanal. Cat News 7, (2012).

6. Zimmermann, A. et al. Every case is different: Cautionary insights about generalisations in human-wildlife conflict from a range-wide study of people and jaguars. Biological Conservation 260, 109185 (2021). 
7. Marchini, S. \& Crawshaw, P. G. Human-Wildlife Conflicts in Brazil: A Fast-Growing Issue.

8. Tortato, F., Layme, V., Crawshaw, P. \& Izzo, T. The impact of herd composition and foraging area on livestock predation by big cats in the Pantanal of Brazil: Livestock predation by big cats in the Pantanal. Animal Conservation 18, (2015).

9. May Júnior, J. A. et al. Mercury content in the fur of jaguars (Panthera onca) from two areas under different levels of gold mining impact in the Brazilian Pantanal. An. Acad. Bras. Ciênc. 90, 2129-2139 (2018).

10. Romero-Muñoz, A., Morato, R. G., Tortato, F. \& Kuemmerle, T. Beyond fangs: beef and soybean trade drive jaguar extinction. Frontiers in Ecology and the Environment 18, 67-68 (2020).

11. Ferreguetti, A. C. et al. Roadkill of medium to large mammals along a Brazilian road (BR-262) in Southeastern Brazil: spatial distribution and seasonal variation. Studies on Neotropical Fauna and Environment 55, 216-225 (2020).

12. Srbek-Araujo, A. C. et al. Jaguar (Panthera onca Linnaeus, 1758) roadkill in Brazilian Atlantic Forest and implications for species conservation. Brazilian Journal of Biology 75, 581-586 (2015).

13. Carvalho, N. C. de, Bordignon, M. O. \& Shapiro, J. T. Fast and furious: a look at the death of animals on the highway MS-080, Southwestern Brazil. Iheringia. Série Zoologia 104, 43-49 (2014).

14. Libonati, R., DaCamara, C. C., Peres, L. F., Carvalho, L. A. S. de \& Garcia, L. C. Rescue Brazil's burning Pantanal wetlands. Nature 588, 217-219 (2020).

15. Leal Filho, W., Azeiteiro, U. M., Salvia, A. L., Fritzen, B. \& Libonati, R. Fire in Paradise: Why the Pantanal is burning. Environmental Science \& Policy 123, 31-34 (2021).

16. Garcia, L. C. et al. Record-breaking wildfires in the world's largest continuous tropical wetland: Integrative fire management is urgently needed for both biodiversity and humans. Journal of Environmental Management 293, 112870 (2021).

17. INPE-Instituto Nacional de Pesquisas Espaciais. Monitoramento dos Focos Ativos por Estado, Região ou Bioma (Pantanal) - (Programa Queimadas, accessed 20 January 2021); http://queimadas.dgi.inpe.br/queimadas/portal-static/estatisticas estados/

18. Pletsch, M. et al. The 2020 Brazilian Pantanal fires. Anais da Academia Brasileira de Ciências 93, (2021).

19. Marengo, J. A. et al. Extreme Drought in the Brazilian Pantanal in 2019-2020: Characterization, Causes, and Impacts. Front. Water 3, (2021).

20. Damasceno-Junior, G. et al. Lessons to be Learned from the Wildfire Catastrophe of 2020 in the Pantanal Wetland. (2021).

21. Lázaro, W. L., Oliveira-Júnior, E. S., Silva, C. J. da, Castrillon, S. K. I. \& Muniz, C. C. Climate change reflected in one of the largest wetlands in the world: an overview of the Northern Pantanal water regime. Acta Limnol. Bras. 32, (2020).

22. INMET, Instituto Nacional de Metereologia. (Banco de Dados Meteorológicos, accessed 31 October 2020); https://bdmep.inmet.gov.br/

23. CPTEC/INPE - Instituto Nacional de Pesquisas Espaciais. Clima Evolução - Evolução Mensal e Sazonal das Chuvas (Região 88), (accessed 31 December 2020); http://clima1.cptec.inpe.br/evolucao/pt

24. CPRM/SGB - Serviço Geológico do Brasil. HidroSeries, Um aplicativo para acesso simplificado aos dados hidrológicos do Sistema Nacional de Informações em Recursos Hídricos (SNIRH) e geração de series históricas (Rede Hidrometereológica Nacional, accessed 31 October 2020); https://apps.cprm.gov.br/hidro-series/

25. MapBiomas - Projeto MapBiomas, Coleção 6.0 and 5.0 da Série Anual de Mapas de Cobertura e Uso de Solo do Brasil (2021), (accessed 15 September 2021);

26. Tomas, W. et al. Counting the Dead: 17 Million Vertebrates Directly Killed by the 2020's Wildfires in the Pantanal Wetland, Brazil. Preprint in review, (2021); doi:10.21203/rs.3.rs859794/v1. 
27. LASA - Laboratório de Aplicações de Satélites Ambientais. Área queimada Pantanal (Universidade Federal do Rio de Janeiro, Version 17/11/2020); https://lasa.ufrj.br/noticias/area-queimada-pantanal-2020/

28. Arruda, W. de S. et al. Inundation and Fire Shape the Structure of Riparian Forests in the Pantanal, Brazil. PLOS ONE 11, e0156825 (2016).

29. de Oliveira, M. T. et al. Regeneration of riparian forests of the Brazilian Pantanal under flood and fire influence. Forest Ecology and Management 331, 256-263 (2014).

30. Silva, S. M. et al. Wildfire against the survival of Xenarthra: anteaters, armadillos, and sloths. bcnaturais 15, 523-532 (2020).

31. Rossi, F. S. \& Santos, G. A. de A. Fire dynamics in Mato Grosso State, Brazil: the relative roles of gross primary productivity. Big Earth Data 4, 23-44 (2020).

32. Thompson, J. J. et al. Environmental and anthropogenic factors synergistically affect space use of jaguars. Current Biology (2021) doi:10.1016/j.cub.2021.06.029.

33. Jędrzejewski, W. et al. Estimating large carnivore populations at global scale based on spatial predictions of density and distribution - Application to the jaguar (Panthera onca). PLOS ONE 13, e0194719 (2018).

34. WMO - World Meteorological Organization. New climate predictions assess global temperatures in coming five years (2020); https://public.wmo.int/en/media/pressrelease/new-climate-predictions-assess-global-temperatures-coming-five-years https://hadleyserver.metoffice.gov.uk/wmolc/WMO_GADCU_2019.pdf

35. Marengo, J., Alves, L. \& Torres, R. Regional climate change scenarios in the Brazilian Pantanal watershed. Clim. Res. 68, 201-213 (2016).

36. Thielen, D. et al. Quo vadis Pantanal? Expected precipitation extremes and drought dynamics from changing sea surface temperature. PLOS ONE 15, e0227437 (2020).

37. FIRMS, F. I. for R. M. S. FIRMS: Fire Information for Resource Management System. Google Developers (2020); https://developers.google.com/earth-engine/datasets/catalog/FIRMS

38. MODIS6 - MODIS Collection 6 NRT Hotspot / Active Fire Detections MCD14DL (2020).

39. Morato, R. G. et al. Jaguar movement database: a GPS-based movement dataset of an apex predator in the Neotropics. Ecology 99, 1691-1691 (2018).

40. Menezes, J. F. S., Tortato, F. R., Oliveira-Santos, L. G. R., Roque, F. O. \& Morato, R. G. Deforestation, fires, and lack of governance are displacing thousands of jaguars in Brazilian Amazon. Conservation Science and Practice (2021), e477; https://doi.org/10.1111/csp2.477

41. Johnson, D. H. The Comparison of Usage and Availability Measurements for Evaluating Resource Preference. Ecology 61, 65-71 (1980).

42. Tomas, W. M. et al. Sustainability Agenda for the Pantanal Wetland: Perspectives on a Collaborative Interface for Science, Policy, and Decision-Making. Tropical Conservation Science 12, 1-30, (2019); https://doi.org/10.1177/1940082919872634.

43. Junk, W., Bayley, P. \& Sparks, R. The Flood Pulse Concept in River-Floodplain Systems. Can. Spec. Public Fish. Aquat. Sci. vol. 106 (1989).

44. Eriksson, C. et al. Extensive aquatic subsidies lead to territorial breakdown and high density of an apex predator. bioRxiv (2021) doi:https://doi.org/10.1101/2021.03.29.437596.

45. Cardoso, H. M. et al. Effectiveness of protected areas for jaguars: the case of the Taiamã Ecological Station in Brazil. Papéis Avulsos de Zoologia 60, (2020).

46. Soisalo, M. K. \& Cavalcanti, S. M. C. Estimating the density of a jaguar population in the Brazilian Pantanal using camera-traps and capture-recapture sampling in combination with GPS radio-telemetry. Biological Conservation 129, 487-496 (2006).

47. Azevedo, F. C. C. de \& Murray, D. L. Evaluation of Potential Factors Predisposing Livestock to Predation by Jaguars. The Journal of Wildlife Management 71, 2379-2386 (2007).

48. Dasgupta, S. Panthera: At least 500 jaguars lost their lives or habitat in Amazon fires. Mongabay Environmental News (2019); https://news.mongabay.com/2019/09/panthera-atleast-500-jaguars-lost-their-lives-or-habitat-in-amazon-fires/

49. Sheppard, S. W. Panthera increases estimate to 500 jaguars left homeless or deceased from Amazon fires. Panthera (2019); https://www.panthera.org/panthera-increases-estimate-500jaguars-left-homeless-or-deceased-amazon-fires. 
50. Estes, J. A. et al. Trophic Downgrading of Planet Earth. Science 333, 301-306 (2011).

51. Cullen Jr, L., Abreu, K. C. de, Sana, D. \& Nava, A. F. D. Jaguars as landscape detectives for the upper Paraná River corridor, Brazil. Natureza \& conservação revista brasileira de conservação da natureza 3, 147 (2005).

52. Boron, V. et al. Jaguar Densities across Human-Dominated Landscapes in Colombia: The Contribution of Unprotected Areas to Long Term Conservation. PLOS ONE 11, e0153973 (2016). 53.

53. De Barros, A. E. et al. Identification of Areas in Brazil that Optimize Conservation of Forest Carbon, Jaguars, and Biodiversity: Optimizing Forest Carbon and Biodiversity Conservation. Conservation Biology 28, 580-593 (2014).

54. Thornton, D. et al. Assessing the umbrella value of a range-wide conservation network for jaguars (Panthera onca). Ecol App/ 26, 1112-1124 (2016).

55. Haag, T. et al. The effect of habitat fragmentation on the genetic structure of a top predator: loss of diversity and high differentiation among remnant populations of Atlantic Forest jaguars (Panthera onca): JAGUAR CONSERVATION GENETICS. Molecular Ecology 19, 49064921 (2010).

56. Gese, E. M., Terletzky, P. A., Cavalcanti, S. M. C. \& Neale, C. M. U. Influence of behavioral state, sex, and season on resource selection by jaguars (Panthera onca): Always on the prowl? Ecosphere 9, e02341 (2018).

57. Morato, R. G. et al. Resource selection in an apex predator and variation in response to local landscape characteristics. Biological Conservation 228, 233-240 (2018).

58. Rabelo, R. M., Aragón, S. \& Bicca-Marques, J. C. Prey abundance drives habitat occupancy by jaguars in Amazonian floodplain river islands. Acta Oecologica 97, 28-33 (2019).

60. Morato, R. G. et al. Space Use and Movement of a Neotropical Top Predator: The Endangered Jaguar. PLOS ONE 11, e0168176 (2016).

61. Alho, C. J. R. et al. Ameaças à biodiversidade do Pantanal Brasileiro pelo uso e ocupação da terra. Ambiente \& Sociedade 22, (2019).

62. Magioli, M. et al. The role of protected and unprotected forest remnants for mammal conservation in a megadiverse Neotropical hotspot. Biological Conservation 259, 109173 (2021).

63. Xavier da Silva, M., Paviolo, A., Tambosi, L. R. \& Pardini, R. Effectiveness of Protected Areas for biodiversity conservation: Mammal occupancy patterns in the Iguaçu National Park, Brazil. Journal for Nature Conservation 41, 51-62 (2018).

64. Sollmann, R., Torres, N. \& Silveira, L. Jaguar Conservation in Brazil: The Role of Protected Areas. Cat News Spec. Issue 4, (2008).

65. Oliveira, M. et al. Lack of protected areas and future habitat loss threaten the Hyacinth Macaw Anodorhynchus hyacinthinus and its main food and nesting resources. Ibis (2021) doi:10.1111/ibi.12982.

66. Almeida-Rocha, J. M. de \& Peres, C. A. Nominally protected buffer zones around tropical protected areas are as highly degraded as the wider unprotected countryside. Biological Conservation 256, 109068 (2021).

67. MMA- Ministério do Meio Ambiente. Unidades de Conservação - Protected Areas. Download de dados geográficos (2020); http://mapas.mma.gov.br/i3geo/datadownload.htm

68. Chaves, J. V. B. \& Silva, J. S. V. Evolução das unidades de conservação no Pantanal no período de 1998 a 2018, Anais 7o Simpósio de Geotecnologias no Pantanal, Jardim, MS, 676-685 (Embrapa Informática Agropecuária/INPE 2018).

69. IMASUL - Instituto de Meio Ambiente de Mato Grosso do Sul. Plano de Manejo do Parque Estadual Nascentes do Rio Taquari (2019); https://www.imasul.ms.gov.br/gestao-deunidades-de-conservacao/unidades-de-conservacao-estaduais/parque-estadual-nascentesdo-rio-taquari/

70. ICMBio- Instituto Chico Mendes de Conservação da Biodiversidade. Unidades de Conservação nos Biomas Brasileiros (2021); https://www.icmbio.gov.br/portal/unidadesdeconservacao/biomas-brasileiros/ 
71. ICMBio/SIMRPPN - Instituto Chico Mendes de Conservação da Biodiversidade/ Sistema

72. UNEP-WCMC and IUCN, Protected Planet: The World Database on Protected Areas (WDPA) [On-line], [December/2020], Cambridge, UK: UNEP-WCMC and IUCN (2020); www.protectedplanet.net.

73. Roque, F. O. et al. Upland habitat loss as a threat to Pantanal wetlands. Conserv Biol 30, 1131-1134 (2016).

74. Kantek, D. L. Z. et al. Jaguars from the Brazilian Pantanal: Low genetic structure, male-biased dispersal, and implications for long-term conservation. Biological Conservation 259, 109153 (2021).

75. Pivello, V. R. et al. Understanding Brazil's catastrophic fires: Causes, consequences and policy needed to prevent future tragedies. Perspectives in Ecology and Conservation (2021); doi:10.1016/j.pecon.2021.06.005.

76. Guerra, A. et al. The importance of Legal Reserves for protecting the Pantanal biome and preventing agricultural losses. Journal of Environmental Management 260, 110128 (2020).

77. Zeilhofer, P., Cezar, A., Tôrres, N. M., Jácomo, A. T. de A. \& Silveira, L. Jaguar Panthera onca Habitat Modeling in Landscapes Facing High Land-use Transformation Pressure-Findings from Mato Grosso, Brazil. Biotropica 46, 98-105 (2014).

78. Tortato, F. R. \& Izzo, T. J. Advances and barriers to the development of jaguar-tourism in the Brazilian Pantanal. Perspectives in Ecology and Conservation 15, 61-63 (2017).

79. Tortato, F. R., Izzo, T. J., Hoogesteijn, R. \& Peres, C. A. The numbers of the beast: Valuation of jaguar (Panthera onca) tourism and cattle depredation in the Brazilian Pantanal. Global Ecology and Conservation 11, 106-114 (2017).

80. Alho, C. \& Silva, J. Effects of Severe Floods and Droughts on Wildlife of the Pantanal Wetland (Brazil)-A Review. Animals 2, 591-610 (2012).

81. Costanza, R. et al. The Value of the World's Ecosystem Services and Natural Capital. Nature 387, 253-260 (1997).

82. Ely, P., Fantin-Cruz, I., Tritico, H. M., Girard, P. \& Kaplan, D. Dam-Induced Hydrologic Alterations in the Rivers Feeding the Pantanal. Front. Environ. Sci. 0, (2020).

83. ANA. Estudos de avaliação dos efeitos da implantação de empreendimentos hidrelétricos. Agência Nacional de Águas e Saneamento Básico (ANA) https://www.gov.br/ana/ptbr/assuntos/gestao-das-aguas/planos-e-estudos-sobre-rec-hidricos/plano-de-recursoshidricos-rio-paraguai/estudos-de-avaliacao-dos-efeitos-da-implantacao-deempreendimentos-hidreletricos (2020).

84. Plano de recursos hídricos da região hidrográfica do Paraguai: resumo executivo. (Agência Nacional de Aguas (ANA), 2018).

85. Junk, W. J. \& Cunha, C. N. de. Pantanal: a large South American wetland at a crossroads. Ecological Engineering 24, 391-401 (2005).

86. IBGE - Instituto Brasileiro de Geografia e Estatística. Biomas e sistema costeiro-marinho do Brasil: compatível com a escala 1:250 000 (2019); https://biblioteca.ibge.gov.br/visualizacao/livros/liv101676.pdf

87. Dinerstein, E. et al. An Ecoregion-Based Approach to Protecting Half the Terrestrial Realm. BioScience 67, 534-545 (2017).

88. Macedo, H. D. A., Stevaux, J. C., Silva, A. \& Bergier, I. Water balance based on remote sensing data in Pantanal. Revista Ra'e Ga 46, 33 (2019).

89. Stevaux, J. C., Macedo, H. de A., Assine, M. L. \& Silva, A. Changing fluvial styles and backwater flooding along the Upper Paraguay River plains in the Brazilian Pantanal wetland. Geomorphology 350, 106906 (2020).

90. Marcuzzo, F. F. N., Rocha, H. M. \& Melo, D. C. de R. Mapeamento da precipitação pluviométrica no bioma pantanal do estado do Mato Grosso. Geoambiente online, 66-84, (2011).

91. Alvares, C. A., Stape, J. L., Sentelhas, P. C., de Moraes Gonçalves, J. L. \& Sparovek, G. Köppen's climate classification map for Brazil. metz 22, 711-728 (2013). 
92. Clarke, R., Eduardo, C., Tucci, C. \& Collischonn, W. Variabilidade Temporal no Regime Hidrológico da Bacia do Rio Paraguai. Revista Brasileira de Recursos Hídricos 8, (2003).

93. Gorelick, N. et al. Google Earth Engine: Planetary-scale geospatial analysis for everyone. Remote Sensing of Environment 202, 18-27 (2017).

94. Cahyono, B., Fearns, P., \& McAtee. Analysing Threshold Value in Fire Detection Algorithm Using MODIS Data. Aceh International journal of science and technology 1, $54: 59$ (2012).

95. US Department of State Office of the Geographer. Global LSIB: Large Scale International Boundary Polygons, Simplified (2017), (accessed 10 January 2021); https://developers.google.com/earth-engine/datasets/catalog/USDOS LSIB SIMPLE 2017.

96. Hijmans, R. J. et al. raster: Geographic Data Analysis and Modeling. (2020). R package version 3.3-13; https://CRAN.R-project.org/package=raster

97. R Core Team. R: A language and environment for statistical computing. (R Foundation for Statistical Computing, Vienna, Austria, 2020).

98. Calabrese, J. M., Fleming, C. H. \& Gurarie, E. ctmm: an R package for analyzing animal relocation data as a continuous-time stochastic process. Methods Ecol Evol 7, 1124-1132 (2016).

99. Fleming, C. H. \& Calabrese, J. M. A new kernel density estimator for accurate home-range and species-range area estimation. Methods Ecol Evol 8, 571-579 (2017).

100. Noonan, M. J. et al. A comprehensive analysis of autocorrelation and bias in home range estimation. Ecol Monogr 89, e01344 (2019).

101. Signer, J., Fieberg, J. \& Avgar, T. Animal movement tools ( amt ): R package for managing tracking data and conducting habitat selection analyses. Ecol Evol 9, 880-890 (2019).

\section{Acknowledgements}

This research was supported by the Coordenação de Aperfeiçoamento de Pessoal de Nível Superior - Brasil (CAPES) - Finance Code 001 and Fundação de Amparo à Pesquisa do Estado de São Paulo - FAPESP 2018/24891-5. We thank the Committee members (Andrea Larissa Boesing, Leandro Reverberi Tambosi, and Eduardo Martins Venticinque) who encouraged us to proceed with the paper idea. We also thank Marcus Suassuna Santos (SGB/CPRM) for his help in accessing hydrological data.

\section{Author Contributions}

A.E.B., P.I.L.K.P., R.G.M., and C.H.F. conceptualized the analysis, A.E.B. undertook the analysis, A.E.B., P.I.L.K.P., R.G.M. led the writing of the manuscript. All co-authors provided text contributions and/or figure feedback.

\section{Competing interests}

The authors claim no competing interests. 


\section{Main text Table}

744 Table 1. Proxy for the number of jaguars affected by fires in the Pantanal between 2005 and 7452020.

\begin{tabular}{|c|c|c|c|c|c|c|c|c|c|}
\hline \multicolumn{6}{|c|}{ Proxy of number of jaguars affected by fire in Pantanal } & \multicolumn{4}{|c|}{ Proxy of number of jaguars in Pantanal } \\
\hline & & Factor effect & & & & & & & \\
\hline Year & Ecoregion & \# Ecoregion/Median & Brazil & Paraguay & Bolivia & Ecoregion & Brazil & Paraguay & Bolivia \\
\hline 2005 & 441 & 2.0 & 301 & 20 & 120 & 1668 & 1159 & 28 & 481 \\
\hline 2006 & 226 & 1.0 & 58 & 9 & 159 & & & & \\
\hline 2007 & 431 & 1.9 & 232 & 11 & 188 & & & & \\
\hline 2008 & 236 & 1.0 & 127 & 8 & 101 & & & & \\
\hline 2009 & 231 & 1.0 & 139 & 15 & 77 & & & & \\
\hline 2010 & 447 & 2.0 & 232 & 9 & 207 & & & & \\
\hline 2011 & 163 & 0.7 & 127 & 6 & 29 & & & & \\
\hline 2012 & 285 & 1.3 & 174 & 15 & 96 & & & & \\
\hline 2013 & 140 & 0.6 & 116 & 4 & 19 & & & & \\
\hline 2014 & 42 & 0.2 & 35 & 2 & 5 & & & & \\
\hline 2015 & 163 & 0.7 & 93 & 8 & 63 & & & & \\
\hline 2016 & 151 & 0.7 & 104 & 13 & 34 & & & & \\
\hline 2017 & 187 & 0.8 & 139 & 9 & 38 & & & & \\
\hline 2018 & 61 & 0.3 & 35 & 2 & 24 & & & & \\
\hline 2019 & 513 & 2.3 & 267 & 15 & 231 & & & & \\
\hline 2020 & 746 & 3.3 & 649 & 15 & 82 & & & & \\
\hline $\begin{array}{c}\text { Median } \\
(2005-2019)\end{array}$ & 226 & & 127 & 9 & 77 & & & & \\
\hline
\end{tabular}

755

756

757

758

759

760

761

762

763

764

765

766

767

768

769

770

771

772

773

774

775

Source: adjusted jaguar density estimates ${ }^{33}$ used as a proxy for the number of jaguars in the Pantanal. The Pantanal ecoregion adopted here comprises the legal boundaries of the Brazilian Pantanal biome ${ }^{86}$ and the Pantanal Ecoregion ${ }^{87}$ within the Upper Paraguay River Basin. 


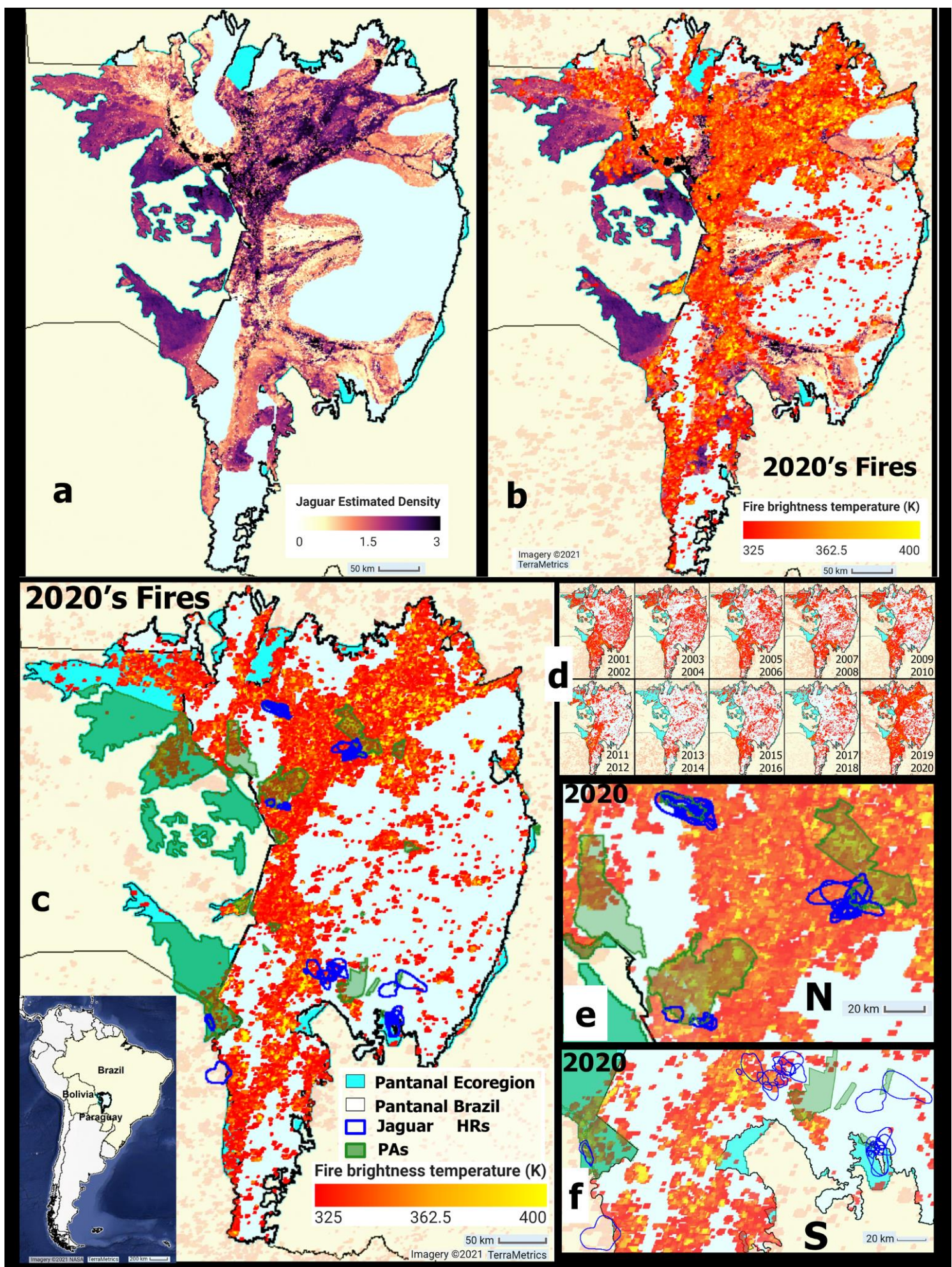

778 Fig. 1. Maps showing the location of the Pantanal and the impact of the 2020 fires $^{37}$ on jaguars. (a) Adjusted 779 jaguar density estimates $33 / 100 \mathrm{~km}^{2}$ used as a proxy for the number of jaguars in the Pantanal. (b) Impact of 780 the 2020 fires on jaguar estimates. (c) Impact of 2020 fires on jaguar home ranges (HRs) and Protected areas 781 (PAs). (d) Biennual impacts of fires since 2001. Northern (e) and southern Pantanal (f) zoomed-in detail. The 782 PAs are represented in green and HRs of resident jaguars in blue. Fire occurrence and its corresponding fire 783 brightness temperature are represented in the scale bar from red to yellow (brightest). 


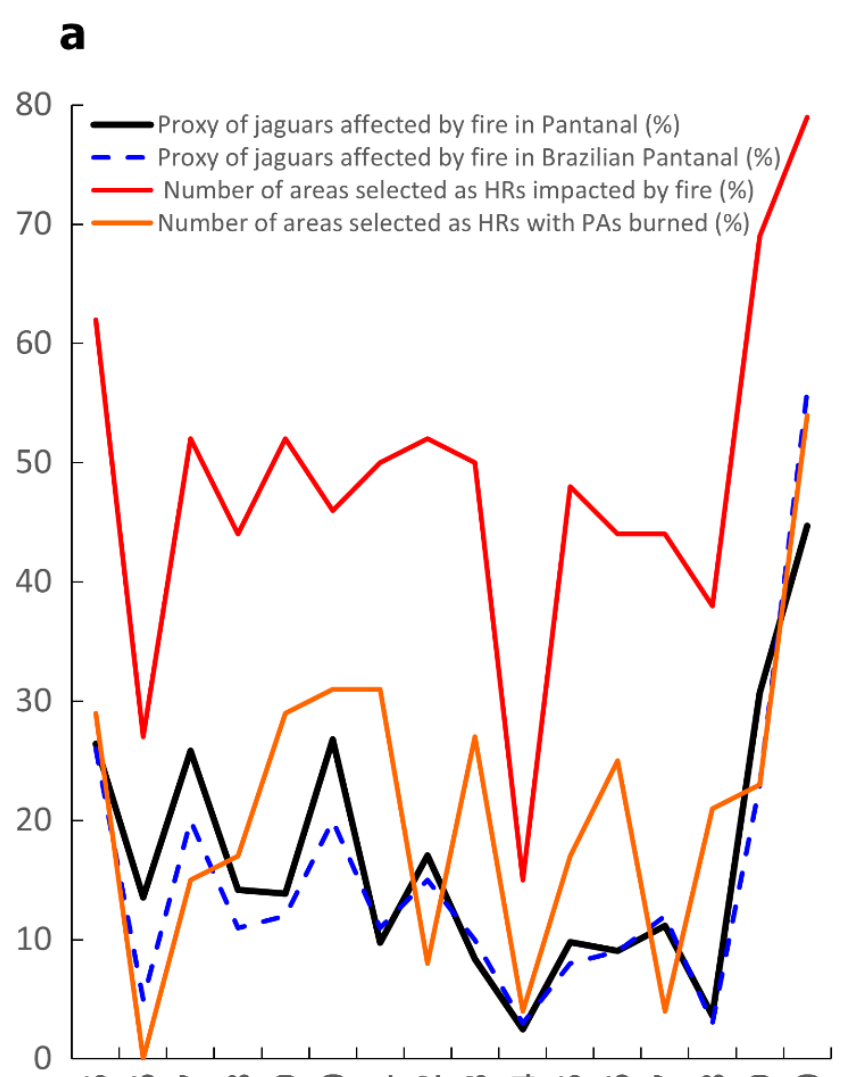

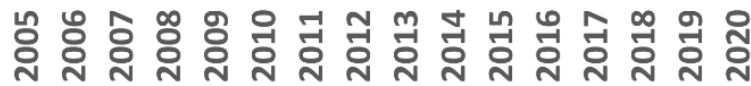
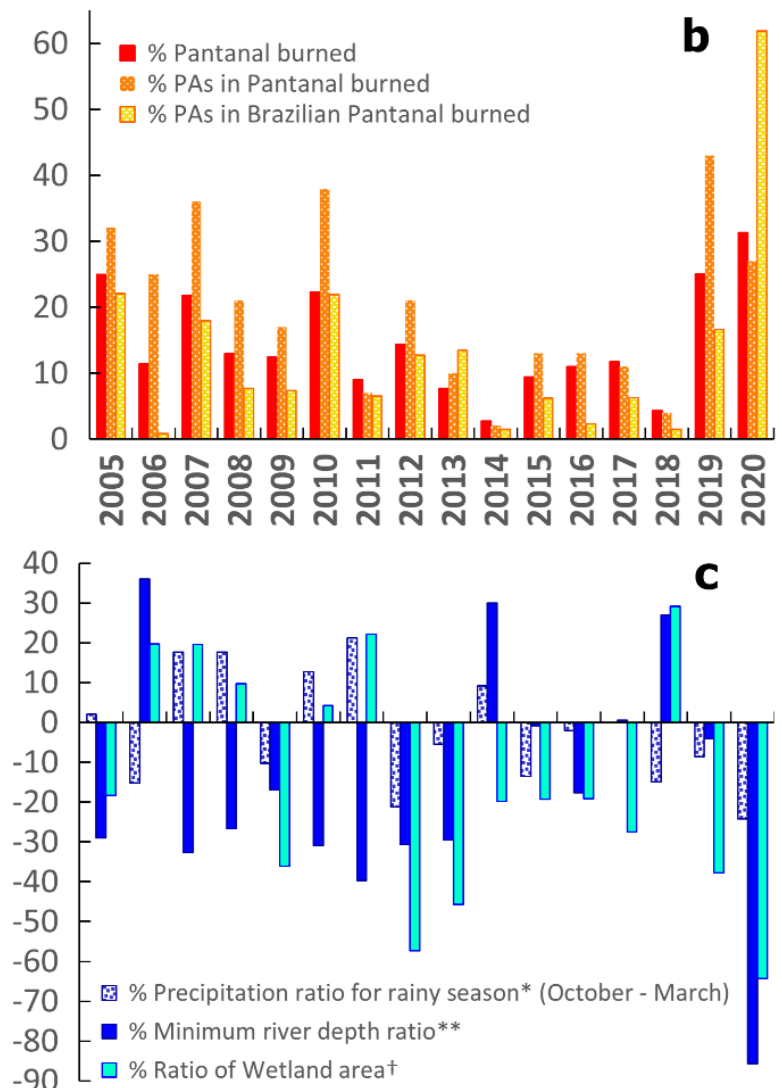

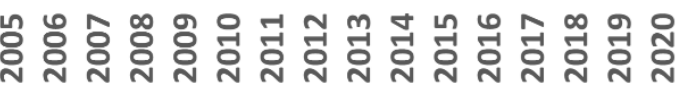

787 Fig. 2. Impacts of fire occurrence from 2005 to 2020 on jaguars. a) Percentage of the proxy number 788 of jaguars, home range areas (HRs), and Protected Areas (PAs) used by jaguars affected by fire 789 throughout and within the Brazilian Pantanal. b) Percentage of the Pantanal and its PAs with fire 790 occurrence. c) Percentage changes in precipitation and river depth (2005-2020) and wetland 791 flooded areas in the Brazilian Pantanal (MapBiomas $\left.6.0^{25}\right){ }^{*} \%$ precipitation ratio for the wet 792 season (October-March) (wet season average of monthly medians from 4 stations/average of wet 793 seasons from multiple years (1967-2019, SI_Figs.S2). ${ }^{* *} \%$ minimum river depth ratio (annual 794 average of minimum river depth from 6 stations/ average (from 6 stations) of the annual medians 795 of minimums (1967-2019, SI_Figs.S2). † \% ratio Wetland area in the Brazilian Pantanal (Total 796 Wetland annual area/Average Total Wetland area (2005-2019, SI_Figs.S2). 


\section{Impact of fires in areas selected as HRs in Pantanal}

Areas selected as Home Ranges by Resident Jaguars (HRs $=48)$
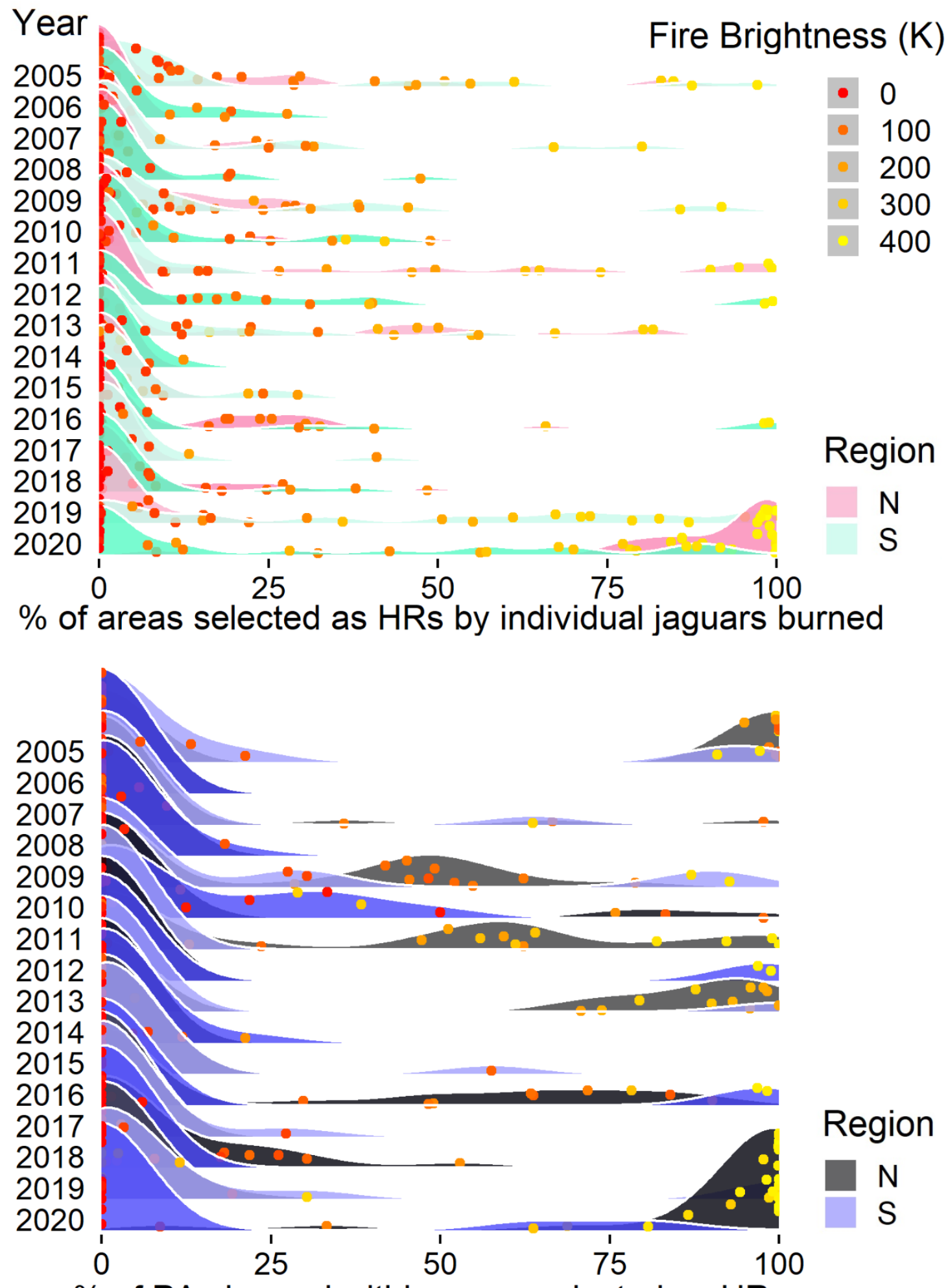

$\%$ of PAs burned within areas selected as HRs

Fig. 3. Smoothed frequency distributions of annual percentages of fire occurrence in the Pantanal from 2005 to 2020. Impact of fires on jaguar home ranges (HRs, top) and PAs available to jaguars within their HRs (bottom). The dots highlight average temperature intensity (fire brightness, in Kelvin) available for each individual for each year. 


\section{Extended Data}

803

804 Figures and tables are numbered below as in the Supplementary Information (and kept in red in 805 the manuscript). 


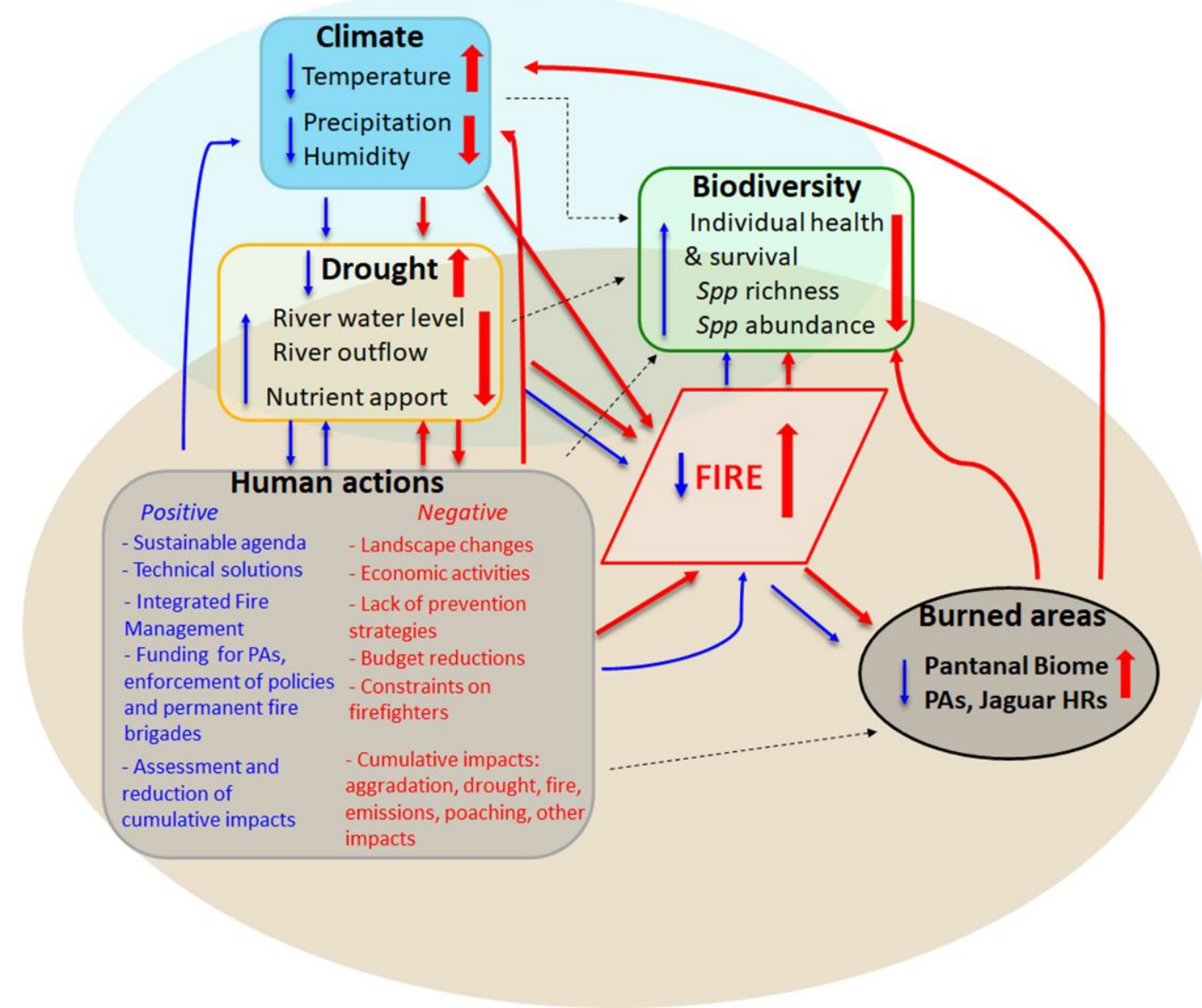

Fig.S1. Scheme summarizing the main impacts of fires in the Pantanal. The red arrows are intentionally larger and show a feedback loop linking increased negative human impacts, climate change, and drought to increased fires and burned areas, with a consequent negative impact on biodiversity. The blue arrows describe a feedback loop for fire control and impact mitigation. The dashed arrows denote other relevant effects in the biome (e.g., cumulative effects from infrastructure such as hydroelectric power plants, river waterways, water and soil pollution from legal and illegal mining and agriculture, poaching and illegal wildlife trade, opportunistic exploitation of burned areas, as well as natural climate constraints). 


\section{Monitored Jaguars}

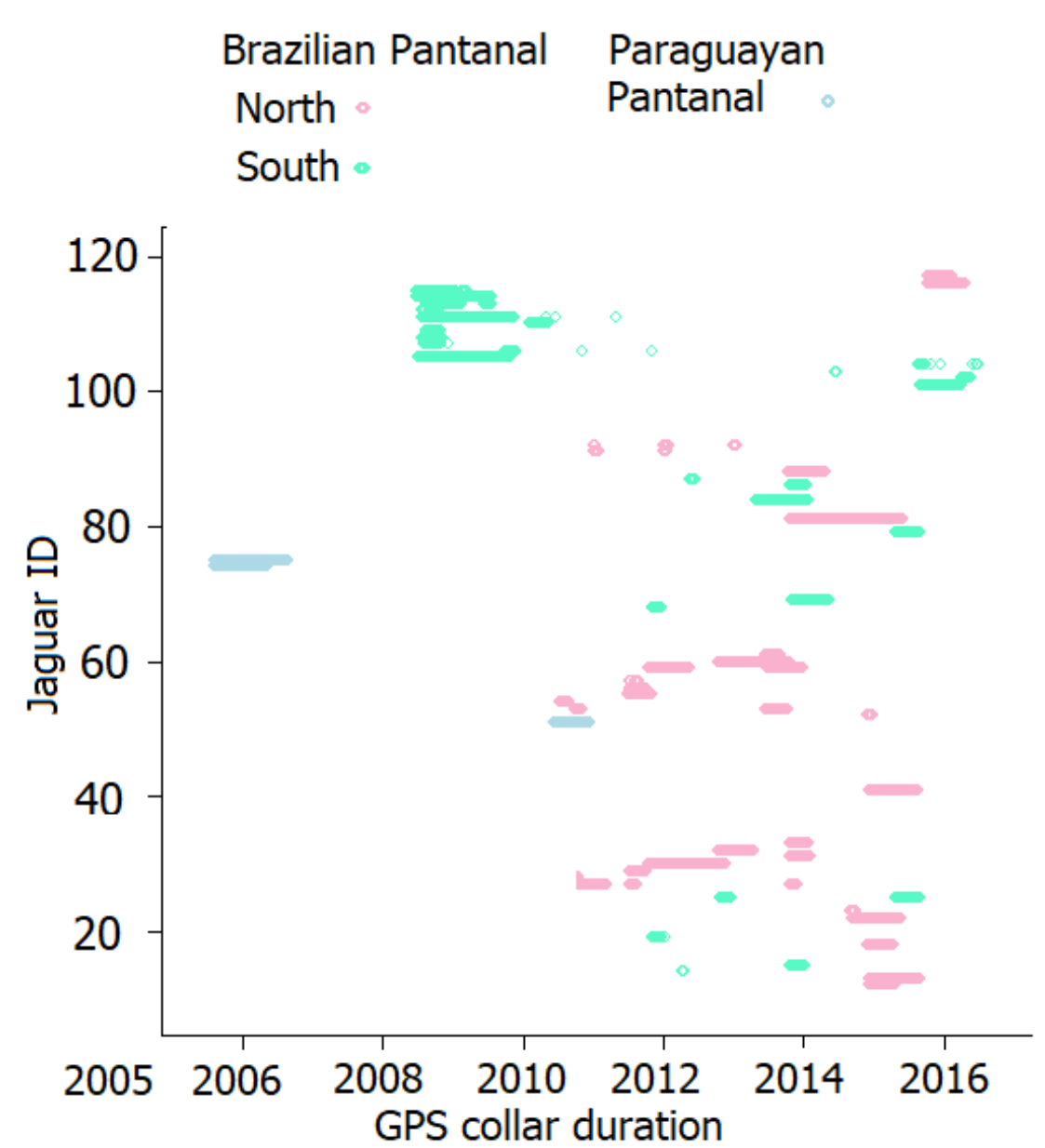

Resident jaguars in Brazilian Pantanal $(n=45)$

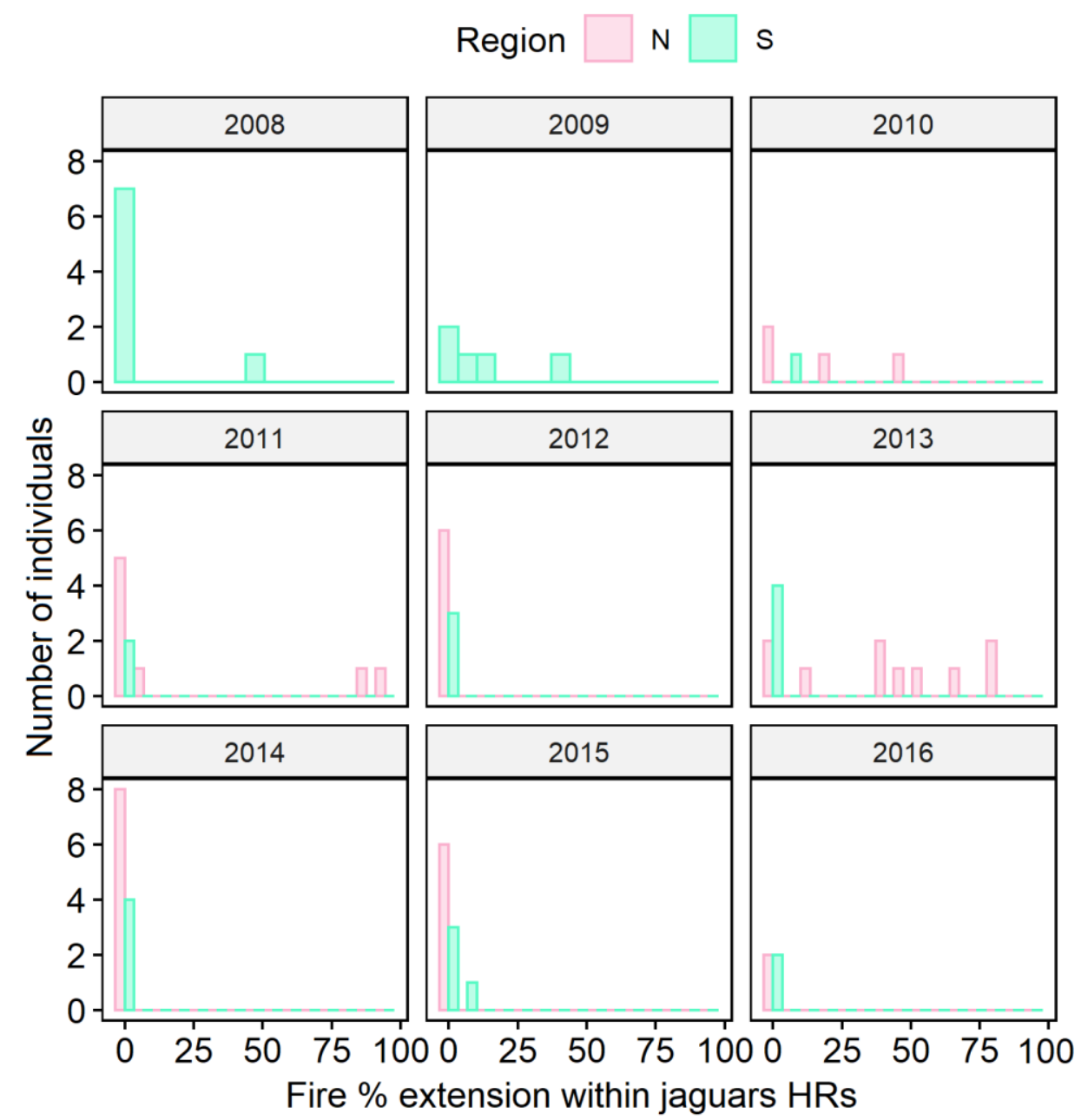

Fig.S3a. The left panel shows the monitoring period for GPS-collared jaguars ${ }^{39}$. The right panel presents the percentage of fire impacting jaguar HRs during the individual monitoring period in the Brazilian Pantanal. 
Not Resident jaguars in Brazilian Pantanal $(n=4)$

Region $\square \mathrm{N} \square \mathrm{s}$

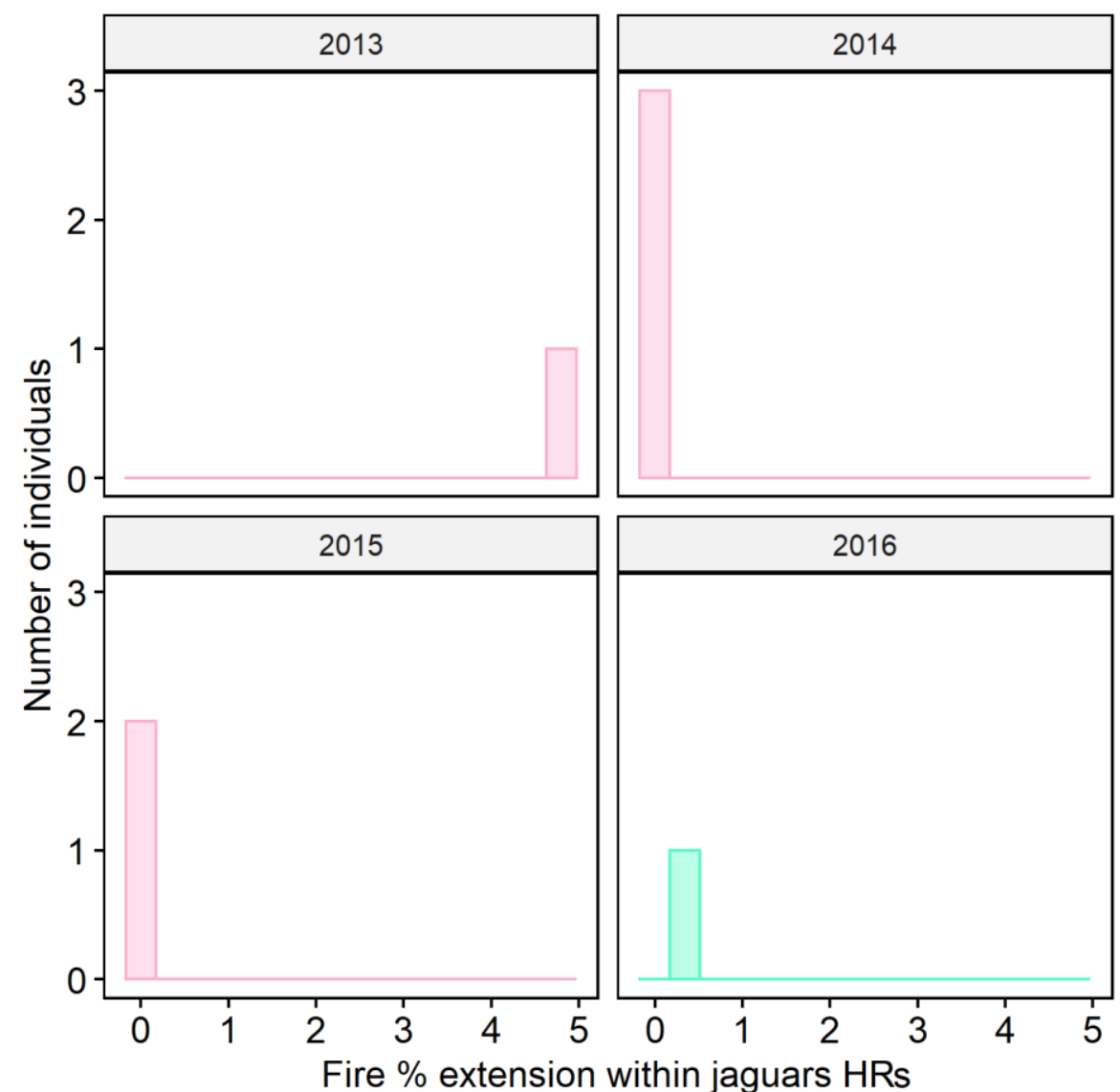

Paraguayan/Bolivian Pantanal $(n=3)$

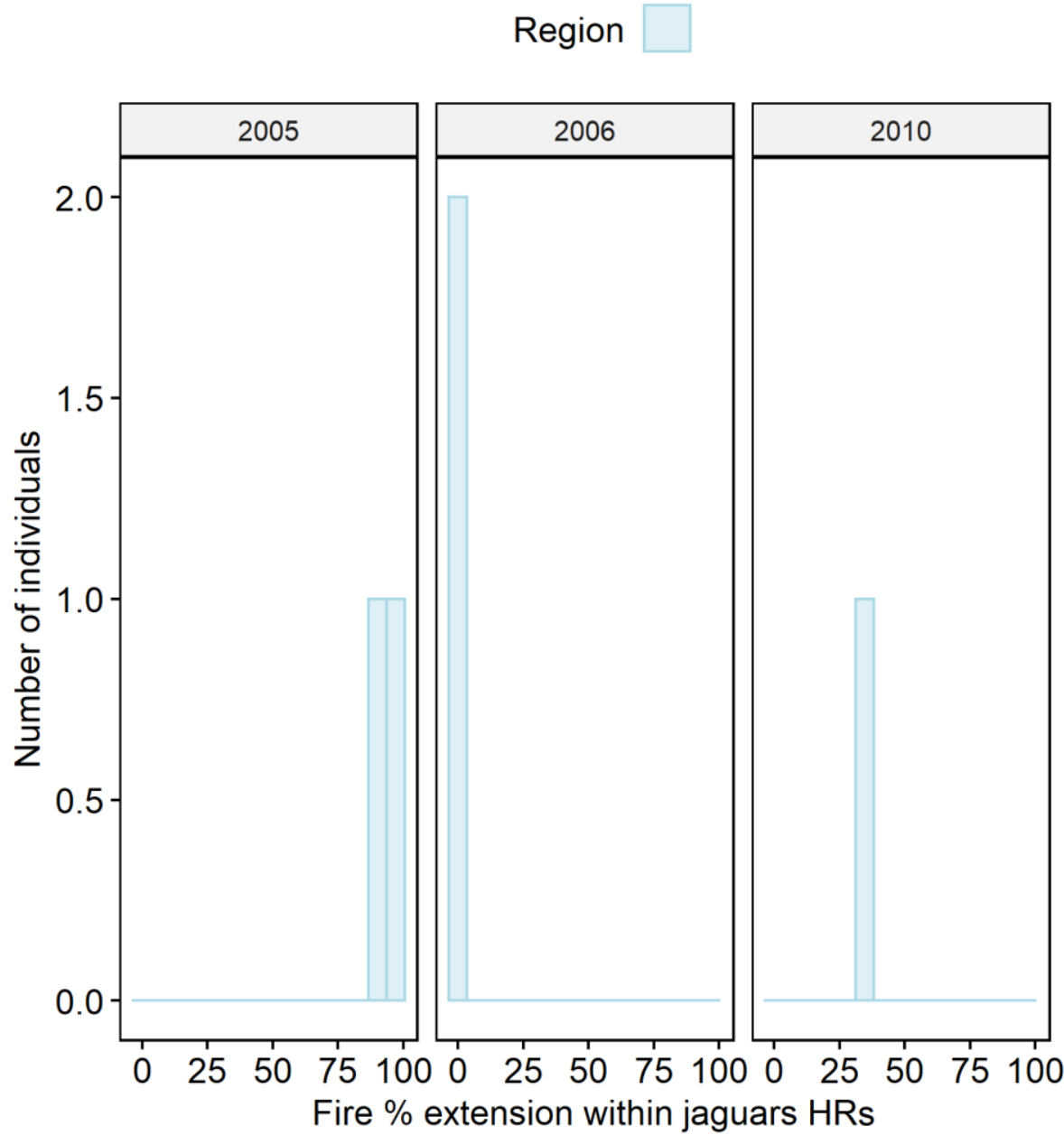

Fig.S3b. Percentage of fire occurrence matching individual jaguar areas during the monitoring period. Non-resident jaguars in Brazil (left) and resident jaguars from Paraguay/Bolivia (right). Note the low fire occurrence within the areas used by non-resident jaguars. 

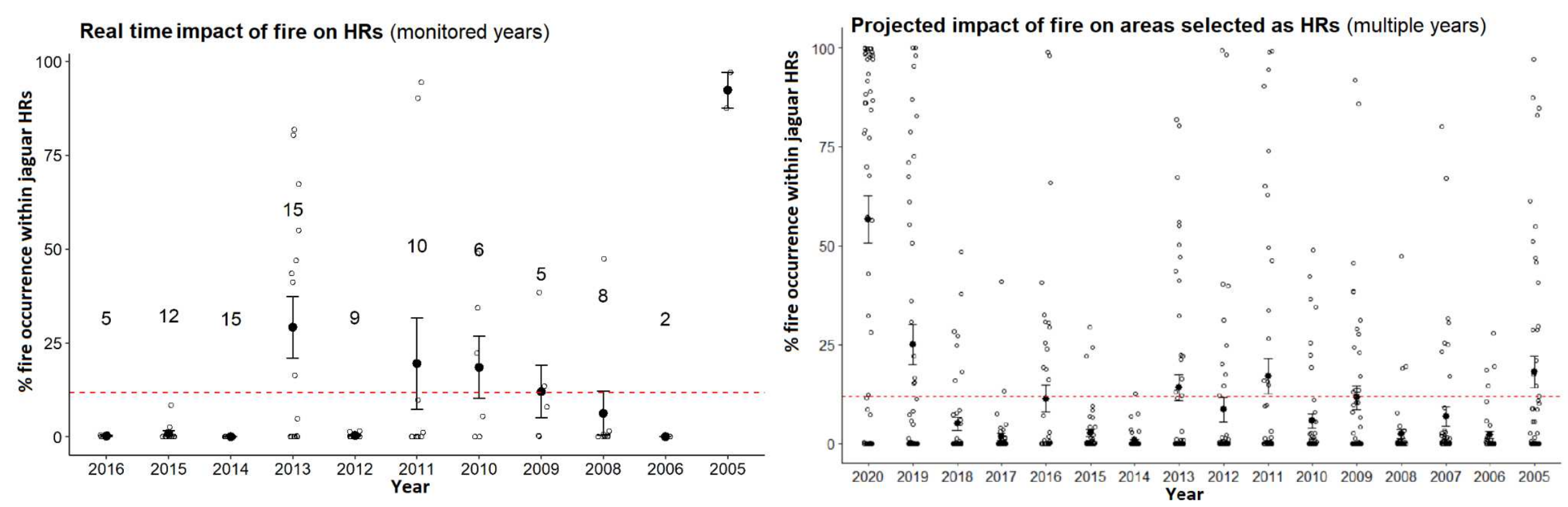

Fig.S3c. (Left) Real-time impact with the percentage of fire occurrence matching individual jaguar areas during the GPS monitoring period. This plot includes 52 individuals from the Brazilian Pantanal (45 residents and 4 non-residents) and the Paraguayan Pantanal ( 3 residents). The numbers in the plot represent the number of individuals monitored each year. (Right) Projected impact of fire on areas selected as home ranges (HRs) of 48 resident individuals from 2005 to 2020 . This projection allowed us to explore the impacts of fire on jaguar HRs for years in which tracking data were unavailable (as was the case for 2020) (see SI_Tab.S2). 


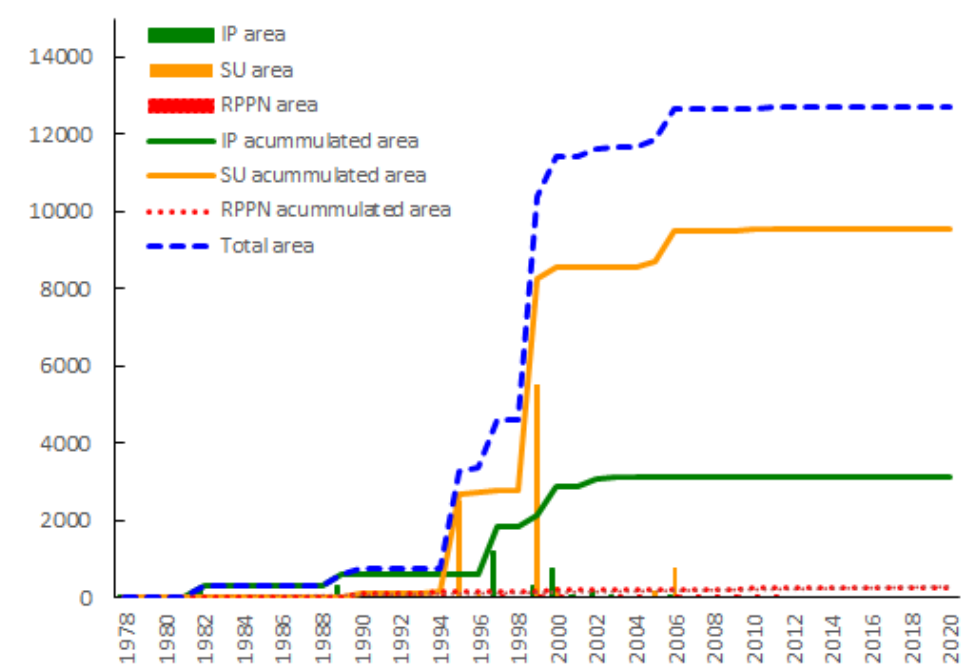

Number of PAs in the Uplands

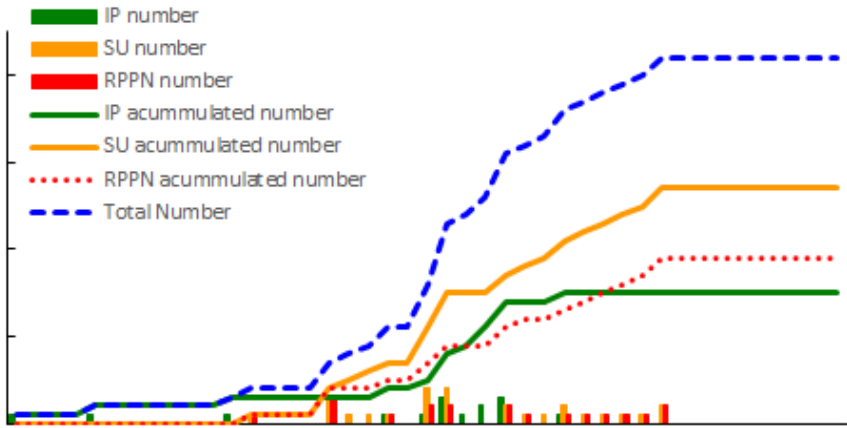

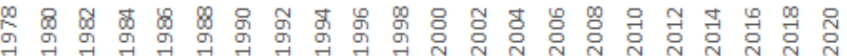

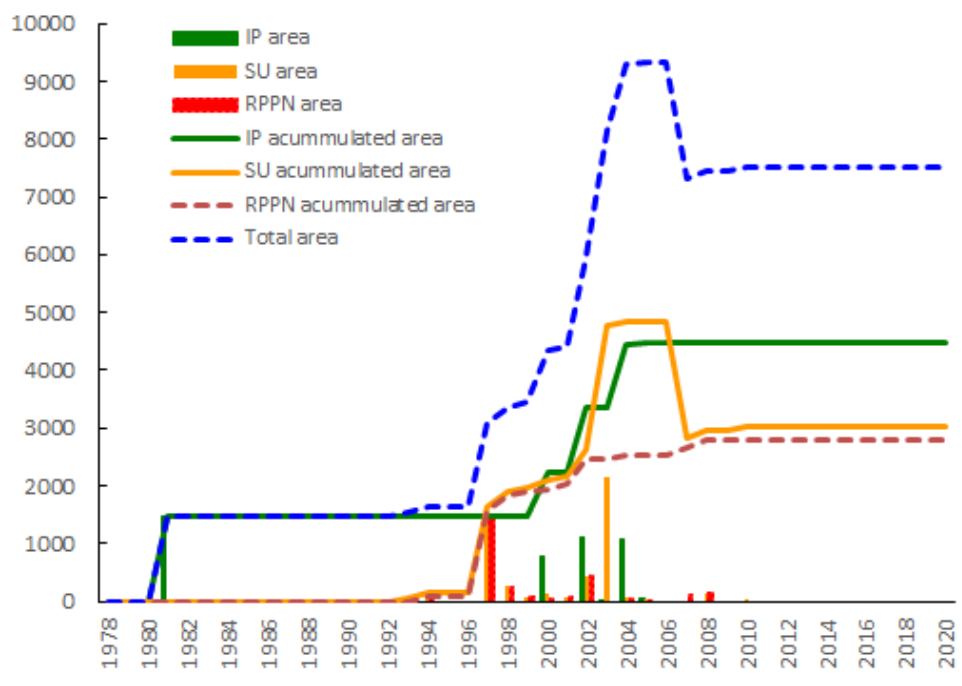

Number of PAs in the Pantanal

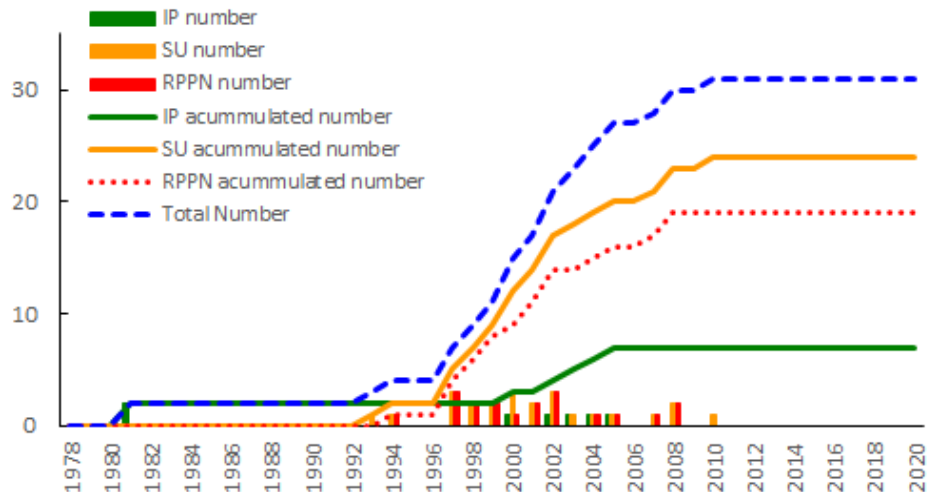

Fig. S5c. Creation and maintenance of

protected areas in the Brazilian Pantanal and the surrounding Uplands within the Brazilian Upper Paraguay River Basin. The upper panels show the accumulated area. The bottom panel show the accumulated numbers. $\mathrm{IP}=$ PAs of Integral Protection. SU $=$ PAs of Sustainable Use. RPPNs = Private Reserves $\mathrm{SU}=\mathrm{PAs}$ that include RPPNs, Park Roads, and other categories of sustainable use. RPPNs are shown in detail, considering that almost $95 \%$ of the Pantanal are on private land. IP areas and RPPNs form most of the PAs in the Pantanal but are a minority in the Uplands. The areas have remained stable since the creation of the last PAs in the Uplands in 2011 and since the revocation of the Environmental Protected Area of Pontal dos Rios Itiquira and Corrientes in 2006 ,

reducing the total of PAs in Pantanal by almost $20 \%$. Adapted from Tomas et al. $2019^{42}$ and Chaves \& Silva $2018^{68}$ using the following sources: MMA 202067. IMASUL $2019^{69}$.

ICMbio 202170; ICMbio - SIMRPPN $2021^{71}$

Data used to make the charts are shown in SI_Tab.S1c 

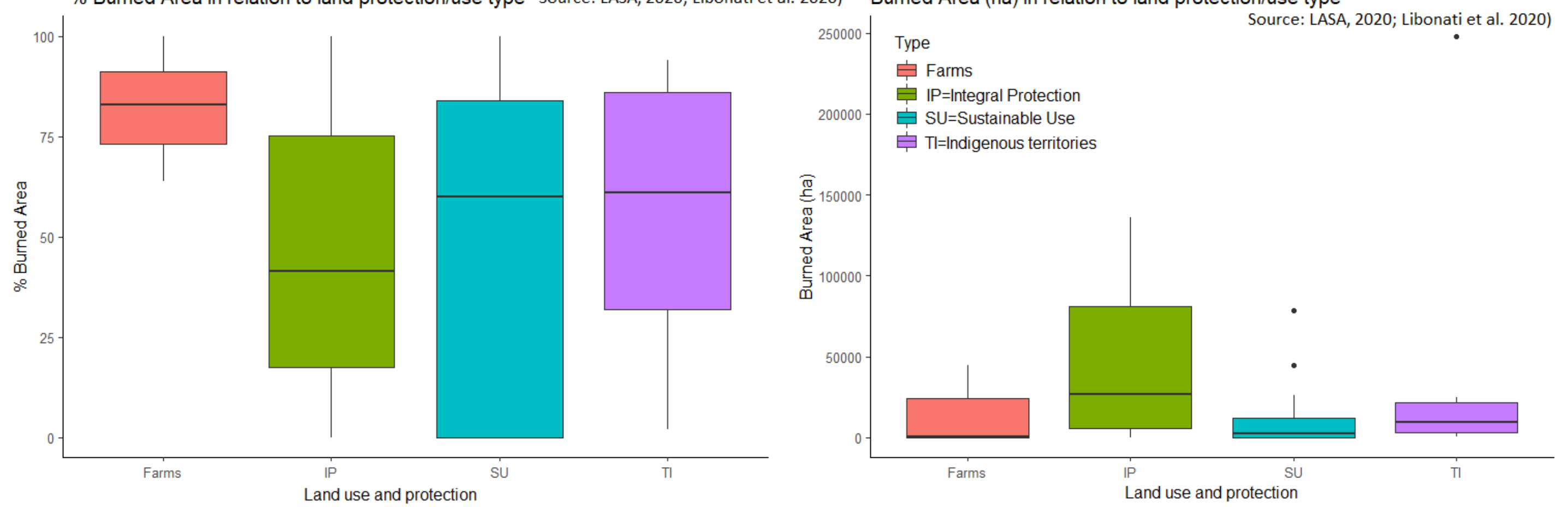

Fig.S5d. Percentage variation (left) and burnt area (right) of the Brazilian Pantanal. Note that farms presented the highest medians for the percentage of burnt areas, while PAs of integral protection presented the highest absolute values of burnt areas. ANOVA applied to evaluate the effect of land protection/use type categories on the percentage and amount of burnt areas found no significant difference $(p>0.05)$ among the category types. Reference sources: LASA ${ }^{27}$, Libonati et al. ${ }^{14}$. Data used in the analyses are shown in SI_Tab.S3. 

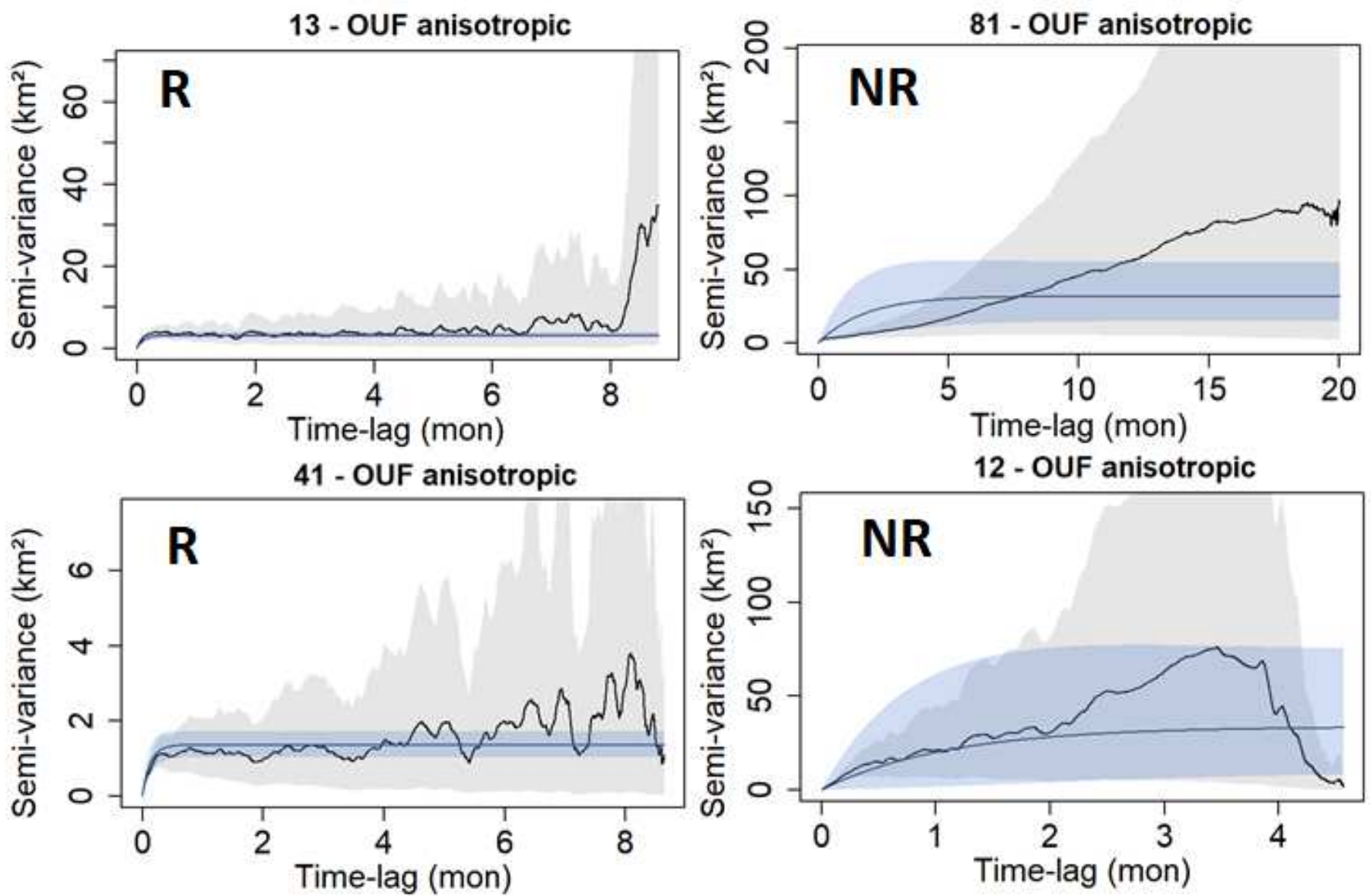

Fig.S6. Variograms of two resident ( $R$, left) and two non-resident (NR, right) jaguars from the Pantanal. The best-fit models are represented by the blue line and their $95 \% \mathrm{Cls}^{98,99}$. Non-resident jaguars lack a clear asymptote despite the long monitoring time, also reflected by a low number of range crossings. Numbers at the top are individual identifiers. OUF anisotropic corresponds to the best-fit model (Ornstein-Uhlenbeck-F), capturing autocorrelated locations and velocities for all R and NR jaguars shown below (see SI_Tab.S4). 


\section{SI_Tables}

Tab.S1a. Areas and percentages of Brazilian protected areas (PAs) in the Pantanal, Uplands, and within Paraguay River Basin (UPRB). Brazilian UPRB corresponds to the basin area in Brazil. Total UPRB corresponds to the total basin area (multiple countries), and Total PRB corresponds to the entire Paraguay River Basin (PRB).

\section{PAs in the Brazilian UPRB (2020)}

REGION BOUNDARY AREA $\mathrm{km}^{2}$ PA area $\mathrm{km}^{2} \quad \% \quad$ number

\begin{tabular}{lrccc}
\hline Brazilian Pantanal & 150355 & 7506 & 5.0 & 31 \\
Brazilian Uplands & 212025 & 12684 & 6.0 & 42 \\
Brazilian UPRB & 362380 & 20190 & 5.6 & 73 \\
Total UPRB & 600000 & 20190 & 3.4 & 73 \\
Total PRB & 1100000 & 20190 & 1.8 & 73 \\
\hline
\end{tabular}

Main sources: adapted from ${ }^{42,68-71}$, Brazilian Pantanal boundary (IBGE) ${ }^{86}$.

Tab. S1b. Comparative between Brazilian PAs in 2020 and the years in which the last area changes occurred. Note that PAs in the Brazilian Pantanal have decreased by almost 20\% since 2007 and have remained the same in the Uplands since 2011.

\begin{tabular}{|c|c|c|c|c|}
\hline \multirow{2}{*}{$\begin{array}{l}\text { Type of PA } \\
\text { Year }\end{array}$} & \multirow{2}{*}{$\begin{array}{r}\text { Pantanal } \\
2006\end{array}$} & \multicolumn{3}{|c|}{ Uplands } \\
\hline & & 2020 & 2011 & 2020 \\
\hline Integral Protection km² & 4491 & 4491 & 3140 & 3140 \\
\hline Sustainable Use km² & 4842 & 3014 & 9543 & 9543 \\
\hline Total km² & 9333 & 7506 & 12684 & 12684 \\
\hline
\end{tabular}

Main sources: adapted from ${ }^{42,68-71}$. 
Tab.S2. Comparative ANOVAs considering the effect of years, location (project_region), and individuals (id) on fire occurrence within jaguar HRs during individual monitoring (monitoring time, HR in blue) or within the assumed home ranges (comparing all years, HR in red). The interaction between year and region exhibited the lowest residuals and the lowest AIC in both comparisons.

\begin{tabular}{|c|c|c|c|c|c|c|c|}
\hline \multirow[t]{3}{*}{ Models } & \multicolumn{3}{|c|}{ Monitoring time (HR) } & \multicolumn{4}{|c|}{ All years (HR) } \\
\hline & \multicolumn{2}{|c|}{ residuals } & $A I C$ & \multirow{2}{*}{\multicolumn{2}{|c|}{$\begin{array}{l}\text { residuals } \\
\quad d f \text { Mean Sq }\end{array}$}} & \multicolumn{2}{|c|}{ AIC } \\
\hline & $d f$ & Mean Sq & $d f \Delta \mathrm{AIC}$ & & & $d f$ & $\triangle A I C$ \\
\hline$*$ interaction <- aov(fires1 year : project_region, data $=$ HR or HR & 63 & 108.1 & 27 & 656 & 169 & 27 & 0 \\
\hline one.way.year <- aov(fires $1 \sim$ year, data $=\mathrm{HR}$ or HR) & 78 & 415.8 & 12108.9 & 752 & 460 & 12 & 549.5 \\
\hline one.way.local <- aov(fires1 project_region, data = HR or HR) & 82 & 561.1 & 8132.0 & 761 & 586 & 8 & 1302.8 \\
\hline two.way <- aov(fires1 $\sim$ year + project_region, data = HR or HR) & 72 & 412.3 & 18113.1 & 746 & 414 & 18 & 530.7 \\
\hline block_ID $<-$ aov(fires $1 \sim$ year + project_region + id, data $=$ HR or HR) & 71 & 414.2 & 19114.2 & 745 & 414 & 19 & 532.7 \\
\hline
\end{tabular}


Tab.S4. Model selection and home range output used for status classification in combination with variograms (ctmm) ${ }^{98,99}$.

\begin{tabular}{|c|c|c|c|c|c|c|c|c|c|c|c|c|c|c|}
\hline $\mathbf{N}$ & $\begin{array}{l}\text { data } \\
\text { id }\end{array}$ & $\begin{array}{l}\text { DOF } \\
\text { area }\end{array}$ & $\begin{array}{l}\tau_{\mathrm{p}} \\
\text { (days) }\end{array}$ & $\begin{array}{l}\tau_{v} \\
(h) \\
\end{array}$ & $\begin{array}{r}\text { duration } \\
\text { (months) }\end{array}$ & model & status & $\begin{array}{l}\text { Total } \\
\text { points }\end{array}$ & start & end & $\begin{array}{l}\text { HR } \\
\left(\mathbf{k m}^{2}\right) \\
\end{array}$ & area $\mathrm{Cl}\left(\mathbf{k m}^{2}\right)$ & project & country \\
\hline 1 & 13 & 68.9 & 3.4 & 0.3 & 8.8 & OUF_ani & $\mathbf{R}$ & 5039 & $07-12-14$ & $24-08-15$ & 52.8 & $(41.1-66)$ & Taiama & Brazil \\
\hline 2 & 15 & 17.5 & 3.9 & 0.5 & 2.6 & OUF_ani & $\mathbf{R}$ & 1257 & $19-10-13$ & 03-01-14 & 352.5 & (206.95 - 536.09) & Oncafari & Brazil \\
\hline 3 & 18 & 26.0 & 4.7 & 0.4 & 4.6 & OUF_ani & $\mathbf{R}$ & 2305 & 29-11-14 & $13-04-15$ & 126.8 & $(82.79-180.03)$ & Taiama & Brazil \\
\hline 4 & 19 & 53.6 & 0.9 & 0.3 & 2.5 & OUF_ani & $\mathbf{R}$ & 741 & $30-10-11$ & $11-01-12$ & 40.2 & $(30.18-51.68)$ & Oncafari & Brazil \\
\hline 5 & 22 & 22.0 & 10.0 & 0.3 & 8.5 & OUF_ani & $\mathbf{R}$ & 4709 & $11-09-14$ & 21-05-15 & 114.0 & $(71.38-166.35)$ & Taiama & Brazil \\
\hline 6 & 25 & 102.5 & 1.6 & 0.2 & 35.3 & OUF_ani & $\mathbf{R}$ & 3074 & $22-10-12$ & $30-08-15$ & 46.2 & $(37.69-55.56)$ & Oncafari & Brazil \\
\hline 7 & 27 & 57.7 & 3.7 & $N A$ & 39.3 & OU_ani & $\mathbf{R}$ & 559 & 21-09-10 & 24-11-13 & 51.2 & $(38.87-65.27)$ & Panthera2 & Brazil \\
\hline 8 & 28 & 40.5 & 2.1 & $N A$ & 3.3 & OU_ani & $\mathbf{R}$ & 205 & 08-07-10 & $13-10-10$ & 33.2 & $(23.77-44.17)$ & Panthera1 & Brazil \\
\hline 9 & 29 & 27.0 & 1.7 & 2.8 & 2.8 & OUF_ani & $\mathbf{R}$ & 67 & 08-07-11 & 30-09-11 & 43.3 & $(28.55-61.15)$ & Panthera1 & Brazil \\
\hline 10 & 30 & 123.1 & 2.9 & $N A$ & 13.6 & ou_iso & $\mathbf{R}$ & 581 & $13-10-11$ & $19-11-12$ & 60.8 & $(50.57-72.05)$ & Panthera2 & Brazil \\
\hline 11 & 31 & 33.2 & 2.2 & $N A$ & 3.5 & ou ani & $\mathbf{R}$ & 103 & 21-10-13 & $01-02-14$ & 31.7 & $(21.84-43.33)$ & Panthera2 & Brazil \\
\hline 12 & 32 & 92.8 & 1.3 & $N A$ & 6.1 & OU_ani & $\mathbf{R}$ & 240 & $15-10-12$ & $12-04-13$ & 100.0 & $(80.7-121.36)$ & Panthera2 & Brazil \\
\hline 13 & 33 & 26.6 & 2.9 & $N A$ & 3.4 & OU_ani & $\mathbf{R}$ & 133 & $22-10-13$ & 29-01-14 & 88.8 & $(58.33-125.62)$ & Panthera2 & Brazil \\
\hline 14 & 41 & 61.0 & 3.8 & 0.3 & 8.6 & OUF_ani & $\mathbf{R}$ & 4951 & $05-12-14$ & $17-08-15$ & 25.5 & $(19.53-32.33)$ & Taiama & Brazil \\
\hline 15 & 52 & 6.5 & 3.6 & 0.3 & 0.9 & OUF_ani & $\mathbf{R}$ & 615 & 27-11-14 & $25-12-14$ & 21.7 & $(8.34-41.33)$ & Taiama & Brazil \\
\hline 16 & 53 & 24.9 & 6.1 & $N A$ & 37.9 & OU_ani & $\mathbf{R}$ & 299 & 20-09-10 & $13-10-13$ & 348.6 & $(225.27-498.39)$ & Panthera2 & Brazil \\
\hline 17 & 54 & 7.3 & 5.1 & 1.6 & 1.5 & OUF_ani & $\mathbf{R}$ & 128 & $12-07-10$ & $26-08-10$ & 36.1 & $(14.79-66.72)$ & Panthera1 & Brazil \\
\hline 18 & 55 & 38.3 & 1.9 & $N A$ & 4.2 & OU_ani & $\mathbf{R}$ & 141 & $26-06-11$ & $28-10-11$ & 91.8 & $(65.04-123.03)$ & Panthera2 & Brazil \\
\hline 19 & 56 & 28.1 & 2.3 & 1.4 & 3.0 & OUF_ani & $\mathbf{R}$ & 109 & 08-07-11 & 04-10-11 & 72.6 & $(48.29-101.88)$ & Panthera1 & Brazil \\
\hline 20 & 59 & 118.0 & 2.5 & 1.9 & 27.1 & OUF_ani & $\mathbf{R}$ & 434 & $15-10-11$ & $23-12-13$ & 241.3 & $(199.72-286.72)$ & Panthera2 & Brazil \\
\hline 21 & 60 & 235.5 & 1.2 & $N A$ & 12.8 & OU_ani & $\mathbf{R}$ & 705 & $10-10-12$ & $23-10-13$ & 88.4 & (77.42 - 99.98) & Panthera2 & Brazil \\
\hline 22 & 61 & 8.6 & 7.0 & 2.3 & 2.4 & OUF_ani & $\mathbf{R}$ & 109 & $18-06-13$ & $28-08-13$ & 343.9 & $(153.75-609.23)$ & Panthera2 & Brazil \\
\hline 23 & 68 & 14.0 & 3.0 & 0.4 & 1.8 & OUF_ani & $\mathbf{R}$ & 996 & 01-11-11 & $23-12-11$ & 242.9 & $(132.71-385.72)$ & Oncafari & Brazil \\
\hline 24 & 69 & 63.9 & 3.0 & 0.3 & 6.7 & OUF_ani & $\mathbf{R}$ & 3304 & $27-10-13$ & $13-05-14$ & 156.6 & $(120.55-197.23)$ & Oncafari & Brazil \\
\hline 25 & 79 & 42.9 & 2.8 & 0.4 & 4.3 & OUF_ani & $\mathbf{R}$ & 2202 & 19-04-15 & $25-08-15$ & 68.9 & $(49.81$ - 90.93) & Oncafari & Brazil \\
\hline 26 & 84 & 114.2 & 2.3 & 0.3 & 9.3 & OUF_ani & $\mathbf{R}$ & 4643 & 21-04-13 & 21-01-14 & 70.4 & $(58.05-83.84)$ & Oncafari & Brazil \\
\hline
\end{tabular}




\begin{tabular}{|c|c|c|c|c|c|c|c|c|c|c|c|c|c|c|}
\hline 27 & 86 & 26.4 & 3.0 & 0.3 & 3.0 & OUF_ani & $\mathbf{R}$ & 1324 & $22-10-13$ & $17-01-14$ & 166.3 & (108.97 - 235.44) & Oncafari & Brazil \\
\hline 28 & 87 & 35.2 & 0.6 & 0.3 & 1.2 & OUF_ani & $\mathbf{R}$ & 398 & $15-05-12$ & $18-06-12$ & 37.4 & $(26.05-50.65)$ & Oncafari & Brazil \\
\hline 29 & 88 & 18.7 & 8.8 & $N A$ & 6.6 & OU_iso & $\mathbf{R}$ & 1289 & $08-10-13$ & $20-04-14$ & 80.2 & $(48.1-120.48)$ & Taiama & Brazil \\
\hline 30 & 91 & 48.3 & 0.7 & 1.8 & 13.1 & OUF_ani & $\mathbf{R}$ & 85 & 01-01-11 & 24-01-12 & 66.8 & $(49.33-86.96)$ & Taiama & Brazil \\
\hline 31 & 92 & 81.6 & 0.2 & $N A$ & 25.3 & OU_ani & $\mathbf{R}$ & 95 & 01-01-11 & $18-01-13$ & 130.8 & $(103.97-160.67)$ & Taiama & Brazil \\
\hline 32 & 101 & 79.5 & 2.1 & 1.2 & 7.3 & OUF_ani & $\mathbf{R}$ & 404 & $26-08-15$ & $29-03-16$ & 302.1 & $(239.34-371.98)$ & RioNegro & Brazil \\
\hline 33 & 104 & 15.4 & 3.3 & 0.6 & 10.4 & OUF_ani & $\mathbf{R}$ & 134 & $22-08-15$ & $23-06-16$ & 481.7 & $(272.14$ - 749.97) & RioNegro & Brazil \\
\hline 34 & 105 & 180.2 & 2.4 & $N A$ & 16.1 & OU_ani & $\mathbf{R}$ & 2111 & 05-07-08 & $22-10-09$ & 105.2 & $(90.43-121.15)$ & SaoBento & Brazil \\
\hline 35 & 106 & 48.2 & 1.0 & 1.5 & 25.9 & OUF_ani & $\mathbf{R}$ & 227 & 24-09-09 & $29-10-11$ & 244.4 & $(180.32-318.01)$ & SaoBento & Brazil \\
\hline 36 & 107 & 19.9 & 3.8 & 0.8 & 4.5 & OUF_ani & $\mathbf{R}$ & 287 & 30-07-08 & $08-12-08$ & 124.8 & $(76.11-185.43)$ & SaoBento & Brazil \\
\hline 37 & 108 & 72.3 & 1.3 & 0.3 & 3.5 & OUF_ani & $\mathbf{R}$ & 481 & 25-07-08 & $06-11-08$ & 142.8 & $(111.77-177.54)$ & SaoBento & Brazil \\
\hline 38 & 109 & 69.6 & 0.6 & $N A$ & 2.7 & OU_ani & $\mathbf{R}$ & 165 & $04-08-08$ & $22-10-08$ & 55.0 & $(42.86-68.68)$ & SaoBento & Brazil \\
\hline 39 & 110 & 53.9 & 1.1 & $N A$ & 3.4 & OU_ani & $\mathbf{R}$ & 166 & $02-02-10$ & $13-05-10$ & 265.8 & $(199.62-341.33)$ & SaoBento & Brazil \\
\hline 40 & 111 & 104.4 & 4.5 & $N A$ & 34.3 & OU_ani & $\mathbf{R}$ & 1757 & $17-07-08$ & 26-04-11 & 58.4 & $(47.73-70.11)$ & SaoBento & Brazil \\
\hline 41 & 112 & 9.5 & 7.5 & $N A$ & 3.0 & OU_ani & $\mathbf{R}$ & 202 & $16-07-08$ & $13-10-08$ & 119.1 & (55.93 - 205.82) & SaoBento & Brazil \\
\hline 42 & 113 & 151.9 & 1.2 & $N A$ & 11.5 & OU_ani & $\mathbf{R}$ & 707 & $11-08-08$ & $15-07-09$ & 40.6 & $(34.4-47.31)$ & SaoBento & Brazil \\
\hline 43 & 115 & 58.0 & 3.9 & 0.9 & 8.9 & OUF_ani & $\mathbf{R}$ & 952 & $20-06-08$ & $10-03-09$ & 123.8 & $(94.02-157.67)$ & SaoBento & Brazil \\
\hline 44 & 116 & 9.0 & 18.3 & 0.4 & 6.4 & OUF_ani & $\mathbf{R}$ & 3340 & $11-10-15$ & $18-04-16$ & 282.0 & $(129.18$ - 493.57) & Taiama & Brazil \\
\hline 45 & 117 & 25.2 & 4.5 & 0.4 & 4.3 & OUF_ani & $\mathbf{R}$ & 2820 & $11-10-15$ & $14-02-16$ & 47.8 & $(30.95-68.13)$ & Taiama & Brazil \\
\hline 46 & 12 & 4.0 & 32.7 & 0.4 & 4.6 & OUF_ani & NR & 2681 & $05-12-14$ & $18-04-15$ & 619.7 & $(169.85-1355.38)$ & Taiama & Brazil \\
\hline 47 & 23 & 3.3 & 8.6 & 0.2 & 0.9 & OUF_ani & NR & 572 & 01-09-14 & $26-09-14$ & 44.8 & $(10.23-104.34)$ & Taiama & Brazil \\
\hline 48 & 81 & $9.45^{*}$ & 52.7 & 0.4 & 20.0 & OUF_ani & NR & 10617 & $15-10-13$ & $29-05-15$ & 591.1 & $(276.34-1023.36)$ & Taiama & Brazil \\
\hline 49 & 102 & 4.6 & 12.2 & 1.1 & 1.9 & OUF_ani & NR & 151 & $29-03-16$ & $23-05-16$ & 567.4 & $(172.2-1193.86)$ & RioNegro & Brazil \\
\hline 50 & 51 & 47.6 & 3.6 & 1.4 & 6.5 & OUF_ani & $\mathbf{R}$ & 727 & $05-06-10$ & $14-12-10$ & 535.7 & (394.46 - 698.22) & PantPy & Paraguay \\
\hline 51 & 74 & 98.6 & 2.6 & $N A$ & 9.1 & OU_ani & $\mathbf{R}$ & 1300 & 09-08-05 & 06-05-06 & 75.4 & $(61.24$ - 90.97) & PantPy & Paraguay \\
\hline 52 & 75 & 74.7 & 4.4 & 1.1 & 12.7 & OUF_ani & $\mathbf{R}$ & 1694 & 09-08-05 & $18-08-06$ & 115.9 & (91.13 - 143.64) & PantPy & Paraguay \\
\hline
\end{tabular}

$\mathrm{N}=$ individual id, data id = correspondent id in Morato et al. datapaper ${ }^{39}, \mathrm{DOF}_{\text {area }}=$ effective number of range crossings, OUF ani $=$ anisotropic Ornstein-Uhlenbeck$\mathrm{F}$ model, OUF_iso = isotropic Ornstein-Uhlenbeck-F model, $\mathrm{R}=$ resident jaguars, NR = non-resident jaguars. PantPy = Paraguayan Pantanal. Note that all non- 
resident jaguars had DOF area < 5, except for individual 81 (which had the largest amount of tracking locations in the dataset); however, observation of the variograms showed that this individual is a non-resident (see SI_Fig.S6) 


\section{Supplementary Files}

This is a list of supplementary files associated with this preprint. Click to download.

- DeBarrosetalJaguarFirePantanalSI.docx 